\title{
An Armamentarium of Wart Treatments
}

\author{
Michelle M. Lipke, MPAS, PA-C
}

\begin{abstract}
Patients and clinicians experience the frustration of cutaneous viral warts caused by infection with the human papilloma virus (HPV). Warts appear in various forms on different sites of the body and include common warts (verruca vulgaris), plane or flat warts, myrmecia, plantar warts, coalesced mosaic warts, filiform warts, periungual warts, anogenital warts (venereal or condyloma acuminata), oral warts and respiratory papillomas. Cervical infection with HPV is now known to cause cervical cancer if untreated. A review of the medical literature reveals a huge armamentarium of wart monotherapies and combination therapies. Official evidence-based guidelines exist for the treatment of warts, but very few of the reported treatments have been tested by rigorous blinded, randomized controlled trials. Therefore, official recommendations do not often include treatments with reportedly high success rates, but they should not be ignored when considering treatment options. It is the purpose of this review to provide a comprehensive overview of the wart treatment literature to expand awareness of the options available to practitioners faced with patients presenting with problematic warts.
\end{abstract}

Keywords: Bleomycin; Cantharidin; Cryotherapy; Diphencyprone; Human papilloma virus; Imiquimod; Laser; Vaccine; Virucidal; Wart

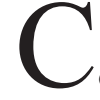
and clinicians since early Greek and Roman times. 1 They can greatly affect a patient's quality of life by causing embarrassment, fear of negative appraisal by others and frustration caused by persistence and/or recurrence. Moderate to extreme discomfort is reported in $51.7 \%$ of patients, and social or leisure activities are affected to a moderate to extreme degree in $38.8 \% .^{2}$

Warts of the genital tract carry a much more ominous and pernicious threat for women in particular. It has been estimated that up to $70 \%$ of sexually active women become infected during their lifetime with human papillomavirus (HPV), the infective agent that causes warts. ${ }^{3-5}$ A causal role for HPV infections in cervical cancer has been documented beyond reasonable doubt. HPV DNA is present in virtually all cervical cancer cases worldwide, with it being detected in $99.7 \%$ of an international series of cervical cancers by genetic amplification techniques and in 100\% of cases as confirmed by histological review. 6,7 Cervical cancer is the most frequent common cancer in developing countries and the second most common cancer in women worldwide. ${ }^{3}$ The

Reprint Requests: Michelle M. Lipke, MPAS, PA-C, Department of Dermatology, Marshfield Clinic-Wausau Center, 2727 Plaza Drive, Wausau, WI 5440I, Tel: 7I 5-847-3463, Fax: 7I 5-847-3482, E-mail: lipke.michelle@marshfieldclinic.org association between HPV infection and cervical cancer is so strong that HPV is now considered the first positive cause of any human cancer ever identified. ${ }^{3}$

This raises the level of concerns over HPV prevention, screening and treatment from that of a nuisance condition to that of a major public health concern. Attention is beginning to focus on the viral factors that determine persistence and neoplastic progression to cancer and the possible role of HPV in other nongenital cancers (e.g., skin, upper aerodigestive tract). ${ }^{8-17}$

Patients with warts seek advice from general practitioners, pharmacists, naturopaths, allied health professionals, family or friends, dermatologists, gynecologists, obstetricians and pediatricians for treatment and may present with recalcitrant warts that have been previously treated with anything from folk remedies to hypnosis to over-the-counter medications to more aggressive clinic-based treatments. Unfortunately, even with years of medical literature on this subject, high-quality, level I evidence for the efficacy of almost all treatments is nonexistent. ${ }^{18-23}$ No treatment has yet proven $100 \%$ effective for a cure. Almost all treatments have some effect in most 
cases. Pain related to treatment, side effects and costs can be determining factors in choosing a therapy. ${ }^{24}$ Even with a single agent, reported efficacies often vary widely and can depend on the patients' ages, compliance and immunocompetence, wart location, form and duration of presence, method of application and skill of the technician. The number of permutations of possible variations in treatment is vast and probably accounts for the lack of good evidence for any one therapeutic regimen.

Evidence-based reviews with guidelines have been published, 18-20,25-29 but these do not cover newer developments or therapies that have yet to be subjected to large, rigorous, blinded, randomized, controlled clinical trials. Simply because a therapy has not been subjected to such rigorous scientific testing does not mean that it is not worth knowing about or worthy of a cautious attempt in difficult cases. Warts have a maddening tendency to either disappear spontaneously making it difficult to know whether the treatment caused the cure, to recur after an apparent total clearance, or to be entirely recalcitrant to all treatments tried. Here we give a brief background of the etiology and pathobiology of HPV and then present a comprehensive list of the therapies and combinations that have been reported in the medical literature.

\section{Etiology}

HPV is a double-stranded DNA virus that causes cutaneous viral warts, most commonly located on the skin and genitalia. ${ }^{30}$ Minor abrasions and infections promoted by maceration of the epithelia most frequently serve as conduits for HPV to the basal keratinocytes, the primary targets for HPV infection. ${ }^{31,32}$ A variety of different strains and variants of HPV have been identified based on DNA studies and serological detection of type-specific antibodies against HPV capsid antigens. Over 118 types of papillomavirus have been identified. ${ }^{33}$ Different HPV types show a preference for either uncornified mucous membranes or cornified stratified squamous epithelium.

The most common warts on the hands and feet are caused by HPV types 1, 2, 4, 27 and 57. ${ }^{19}$ More than 35 types of HPV infect the genital tract. ${ }^{33}$ Types 6 and 11 are associated with low risk anogenital warts, and types 16, 18, 31, 33, 45 and 59 are most commonly associated with squamous cell and adenocarcinomas of the cervix. 3,6,34-37 Individuals are likely to be infected by multiple types. ${ }^{38,39}$ The different types can behave synergistically to facilitate concurrent or subsequent infection with another type. Others can act antagonistically to interfere with one another. 40 Viral activity likely depends on the immune status and response of the infected individual. ${ }^{41}$ Seroconversion after natural infection is a relatively slow process and is dependent upon viral load or persistent infection. $^{42}$ Recurrence after clinical cure is often due to latent virus versus reinfection. ${ }^{1}$ The presence of HPV DNA in subclinical or latent forms can be detected by nested polymerase chain reaction and hybridization. 1,43
Transmission of warts occurs from direct person-to-person contact or indirectly by fomites. Swimming pools and bathrooms are common areas for the spread of warts if the skin is macerated and touches rough surfaces. ${ }^{20}$ Once HPV has infected the skin, autoinoculation can occur by scratching, shaving or traumatizing the skin. ${ }^{22,23}$

Nongenital warts occur in $7 \%$ to $10 \%$ of the general population, with the incidence peaking between the ages of 12 and 16 years. ${ }^{44}$ Viral warts occur equally in both sexes in children ages 2 to 12 years and are among the three most common dermatoses treated. $31,45,46$ Approximately 23\% of warts regress spontaneously within 2 months, 30\% within 3 months and $65 \%$ to $78 \%$ within 2 years. ${ }^{20}$ Previously infected patients have a higher risk for development of new warts than those never infected. ${ }^{47,48}$ The rate of clearance is influenced by factors such as viral type, host immune status, extent and duration of warts. ${ }^{1,44}$

\section{Diagnosis}

The clinical picture of cutaneous warts differs by specific location on the body. Verruca vulgaris (common warts) are hyperkeratotic, exophytic and dome-shaped papules or nodules especially located on fingers, hands, knees, elbows or any other sites of trauma. ${ }^{31}$ Plane or flat warts are flat topped papules with minimal scaling and only slight elevation and are 2-4 $\mathrm{mm}$ in diameter. Intermediate warts can show features of both common warts and flat warts. Myrmecia are large, deep, burrowing warts. ${ }^{49}$ Plantar warts can be painful due to their callused, endophytic papules that have deeply penetrating sloping sides and a central depression. ${ }^{31}$ Numerous coalesced warts on the plantar surface will form a tile-like pattern known as mosaic warts. ${ }^{22,23}$ Filiform warts are most often seen on the face with characteristic frond-like projections that exhibit quick proliferation.22,23 Periungual warts occur anywhere along the nail margins, including the proximal nail fold and hyponychium, which can subsequently lead to onychodystrophy from nail matrix damage and onycholysis from nail bed warts. ${ }^{50}$ Nail biters commonly exhibit multiple periungual warts involving several nails. ${ }^{50}$ Anogenital warts (venereal or condyloma acuminate) occur in the perineum and on the genitalia or in the genital tract and are one of the most common sexually transmitted diseases. They can be an indication of sexual abuse in children under the age of 3, but may be transmitted to the neonates of infected women. ${ }^{20,43}$ HPV infections of the genital tract can also be transmitted to the respiratory tract of a newborn child causing juvenile-onset recurrent respiratory papillomatosis. ${ }^{51}$ Oral warts are small pink or white papules on the oral mucosa. ${ }^{52-54}$ The clinical appearance of warts varies with location, but they are easily diagnosed by a trained clinician.

\section{Differential Diagnosis}

Warts are identified by a change in the regular papillary skin lines with independent vascular sources. When warts resolve, normal dermatoglyphics return. ${ }^{55}$ Dilated capillaries in the wart bleed subsequent to shaving the hyperkeratotic surface. ${ }^{31}$ 
These capillaries help to differentiate warts from corns or calluses. ${ }^{22,23} \mathrm{HPV}$ can masquerade as a seborrheic keratosis, callus, corn, lichen planus, epidermal nevus, molluscum contagiosum or squamous cell carcinoma. ${ }^{56}$ An irritated achrocordon may resemble a wart. The extremities may demonstrate acrokeratosis verruciformis or epidermodysplasia verruciformis in the form of verrucous papules. Syphilitic condylomata must also be kept in mind in the differential diagnosis of anogenital warts. ${ }^{57}$ Amelanotic melanoma must also be considered in a persistent wart. ${ }^{31}$ Genetic amplification techniques combined with genotyping can determine the specific HPV type(s) involved in the infection. However, knowledge of the HPV genotype in benign warts does not influence choice of therapy. ${ }^{20}$

\section{Histopathology}

Warts are usually diagnosed by their clinical appearance, but a histological examination may need to be performed for warts resistant to treatment and for verrucous lesions in immunocompromised individuals. Histologically, a wart demonstrates acanthotic epidermis with papillomatosis, hyperkeratosis and parakeratosis with elongated rete ridges often curving towards the center of the wart. Dermal capillary vessels are prominent and may be thrombosed, and mononuclear cells may be present. HPV-associated papilloma are characterized by large keratinocytes with an eccentric, pyknotic nucleus surrounded by a perinuclear halo (koilocytes). HPV infected cells may have small eosinophilic granules and diffuse clumps of basophilic keratohyaline granules and are not HPV particles. Flat warts have less acanthosis and hyperkeratosis and do not contain parakeratosis or papillomatosis, but they do have abundant koilocytes. Anogenital warts may express slight to extensive acanthosis and parakeratosis since they are within or adjacent to a mucosal surface and do not have a granular layer. Koilocytes are often observed in anogenital warts, and the rete ridges often form thick bands extending extensively into the underlying, highly vascular dermis. ${ }^{57}$

\section{Treatment}

There is currently no cure for HPV infection, and therapy does not affect transmissibility. ${ }^{30}$ Therefore, current therapy aims at eliminating signs and symptoms. No single treatment is fully effective in all patients. Different types of warts may need different site-dependent treatments, and treatments may need to be combined. ${ }^{20}$ Spontaneous regression of warts must be considered in researching the effectiveness of treatment. ${ }^{20}$ The ultimate wart treatment would resolve all or a great percentage of warts, be painless, need only one or a part of a wart treated, call for one to three treatments, create no scarring, offer HPV immunity for a lifetime and be available to all patients. ${ }^{56}$ In 1995, the American Academy of Dermatology developed criteria for the indications for wart treatment ${ }^{56}$ including: 1) the patient's desire for therapy, 2) symptoms of pain, bleeding, itching or burning, 3) disabling or disfiguring lesions, 4) large numbers or large sizes of lesions, 5) the patient's desire to prevent the spread of warts to unblemished skin of self or others, and 6) an immunocompromised condition. Anogenital warts should receive special consideration and warrant vigilance for other sexually transmitted diseases.

For common warts, if receiving no treatment is acceptable to the patient, this is a viable option. However, warts are less likely to resolve spontaneously and are more resistant to treatment in adults, in immunosuppressed patients and in those with persistent warts. ${ }^{20}$ An armamentarium of wart treatments exists, including over-the-counter treatments and therapies provided by primary care and dermatology offices. Because so few of the reported treatments have undergone rigorous clinical trials, rather than weighing the evidence for or against any particular treatment, we offer a comprehensive list of treatments that have been reported in the medical literature.

\section{Folk and Alternative Remedies}

\section{Folklore}

Historic folk remedies have included many variants: "Rub a dusty, dry toad on warts, and they will disappear", or the advice of Tom Sawyer to "...back up against the stump and jam your hand in and say, 'Barley-corn, barley-corn, Injun-meal shorts, / Spunk water, spunk water, swaller these warts." 58 Before these remedies are scoffed at, they serve as a reminder that many warts resolve spontaneously regardless of the treatment or lack thereof. 59

\section{Hypnosis/Suggestive Therapy}

For many years there have been sporadic reports of wart cures in both adults and children through hypnosis or autosuggestive therapy. ${ }^{60-66}$ These are largely case reports or small case series with no controls for comparison with spontaneous regression rates. It is feasible that if hypnosis or suggestion could stimulate the immune system during therapy for wart treatment, as has been suggested in cancer cases, then there could be a basis for hypnotic benefits. However, this remains untested. $67-69$

\section{Garlic Extracts}

Components of garlic (Allium sativum) have been shown to have antiviral activity and to inhibit cellular proliferation of virally infected cells. ${ }^{70,71}$ In one placebo-controlled trial, the application of chloroform extracts of garlic was reported to result in the complete resolution of cutaneous warts with no recurrence after 3-4 months. ${ }^{72}$

\section{Duct Tape}

Occlusive duct tape treatment was championed by Dr. Jerome Litt in a 1978 article. ${ }^{73}$ This treatment has become popular again due to a journal article in 2002 by Focht et al comparing duct tape treatment with cryotherapy. ${ }^{74}$ Their study included 61 patients aged 3 to 22 years being treated for common warts who were randomized to cryotherapy or duct tape arms of therapy. The cryotherapy treatment consisted of treatment every 2 to 3 weeks with a 10 second application of 
liquid nitrogen for up to six treatments. The duct tape arm involved applying a piece of duct tape the size of the wart directly to the wart and removing it 6 days later. An emery board or pumice stone was then used to scrub the wart after soaking it in water. The wart was left open to the air overnight. The 6-day cycle was repeated the following morning. This process was repeated for up to 2 months. ${ }^{74}$

Warts completely resolved in $85 \%$ of the duct tape arm of the study versus only $60 \%$ in the cryotherapy group. 74 The mechanism by which duct tape acts remains speculative. Distant warts that were not treated with the duct tape also resolved, raising the possibility that the host's immune system was stimulated through local irritation produced by the duct tape. There were no reported side effects with using the duct tape, and most warts resolved within 1 month of treatment. ${ }^{74}$ This is an optimal approach to treating children with warts, because it is painless and cost effective. More studies are required before this can be considered an evidence-based treatment, however.

\section{Destructive Therapy}

Destructive therapy should not be confused with virucidal therapy. Destructive therapies are designed to damage or remove the lesion, rather than to kill the virus. These range from surgical curettage to cautery to caustic chemical ablation, and from cryotherapy to hyperthermic therapy. Many of the following approaches may be used with most warts. However, some warn against using destructive approaches for flat warts due to their tendency to Koebnerize. ${ }^{20}$ It should be noted, however, that the reported phenomenon of peripheral wart spread around the margins of the traumatized wart represents either a seeding by HPV viruses or a failure to treat subclinical marginal infected tissues. Therefore, it is more properly categorized as a pseudo-Koebnerization..$^{75-78}$

\section{Surgical Removal by Curettage or Cautery}

Surgical removal of warts by curettage followed by cautery was an early and still widely practiced method of treatment. Success rates of $65 \%$ to $85 \%$ have been reported, but scarring and recurrence occur in up to $30 \%$ of patients. ${ }^{79-82}$ Scarring can be particularly problematic on the sole of the foot, so this technique is most commonly used for filiform warts on the limbs and face.

Surgical excision and cautery of warts is not recommended as a standard therapy because it can be painful and cause scars that are difficult to treat. ${ }^{83}$ Like any destructive therapy, there is no assurance that the wart will not recur. Recurrence rates can be as high as $30 \%{ }^{20}$ Recurrence has been attributed to the recrudescence of latent virus adjacent to the original wart. ${ }^{1}$ No randomized, controlled trials for this treatment have been published. ${ }^{18}$

\section{Chemical Cautery}

Silver nitrate is probably most widely recognized in its historical use to prevent conjunctivitis in newborns, ${ }^{84}$ but in recent times it has largely been supplanted by antibiotic eye drops. The use of silver nitrate has also been used to chemically cauterize epithelial tissues in the treatment of pyogenic and umbilical granulomas, epistaxis, corns and warts. ${ }^{85-89}$ This treatment for warts is currently more widely used in the United Kingdom where non-prescription 95\% silver nitrate caustic applicator pencils are available. ${ }^{90}$ In the United States, however, the Food and Drug Administration has warned consumers that "all over-the-counter (OTC) drug products containing colloidal silver ingredients or silver salts for internal or external use are not generally recognized as safe and effective and are misbranded." 91 Clinical application should be done with caution to avoid excessive burns and irreversible tissue staining. Clinical efficacy is moderate. Clearance was achieved in $43 \%$ with improvement in an additional $26 \%$ after 1 month by application of silver nitrate three times over 9 days. Placebo treatment resulted in $11 \%$ clearance and $14 \%$ improvement. ${ }^{92}$

\section{Salicylic Acid}

Salicylic acid is a first-line therapy that many patients choose, since it is available over the counter. It is a keratolytic therapy with a mechanism of action that slowly destroys virus-infected epidermis and may cause an immune response from the mild irritation caused by the salicylic acid. ${ }^{20}$ It is prepared in concentrations from $10 \%$ to $60 \% .{ }^{93}$ Over-the-counter preparations are available as $17 \%$ salicylic acid combined in a base of flexible collodion or as a $40 \%$ salicylic acid plaster patch. ${ }^{94}$ The advantages of over-the-counter salicylic acid include convenience, minimal expense, negligible pain and reasonable effectiveness. ${ }^{22,23}$ Disadvantages are that results require weeks to months of treatment, and the patient must strictly adhere to instructions. ${ }^{22,23}$ Side effects can include occasional contact dermatitis due to colophony in the collodion base. ${ }^{1,95}$ There is also a potential risk of systemic toxicity in children that can be avoided if lower concentrations or limited areas of treatment are used. ${ }^{1}$

Patient compliance with salicylic acid treatment is extremely important. The wart(s) should be soaked in warm water for 5 minutes before debridement of the dead, hyperkeratotic tissue with an emery board or pumice stone. The salicylic acid preparation should then be applied to the debrided wart. ${ }^{93}$ Salicylic acid liquid should be applied every day, and patches must be reapplied every 48 hours. ${ }^{22,23}$ Acids are particularly well suited for use in children, but precautions should be taken to prevent them from putting the treated area in their mouths. Acids are also appropriate for plantar warts and sensitive body parts where cryotherapy would be painful. ${ }^{22,23}$ Salicylic acid has been applied to plantar warts with some success via iontophoresis. ${ }^{77,96}$

Gibbs et al ${ }^{19}$ reviewed 13 trials that assessed topical salicylic acid in concentrations from $15 \%$ to $60 \%$ with most trials using $15 \%$ to $26 \%$ with or without lactic acid. Data pooled from six placebo-controlled trials demonstrated a cure rate of $75 \%$ (144 of 191) in the salicylic acid treatment arm 
compared with $48 \%$ (89 of 185) in the placebo arm (odds ratio $3.91,95 \%$ confidence interval 2.40 to 6.36$).{ }^{19}$ Monotherapy with 5-fluorouracil, glutaraldehyde, benzalkonium, cryotherapy or podophyllin proved no more effective than salicylic acid-containing paints. Plantar warts may be more amenable to treatment with salicylic acid with occlusion than hand warts. ${ }^{97}$ Wart paints should not be used to treat facial warts because of severe irritation and a potential for scarring. ${ }^{20}$

\section{Cantharidin}

Cantharidin is derived from the blister beetle, Cantharis vesicatoria. ${ }^{83}$ It causes epidermal cell death, acantholysis, and clinical blister formation by interacting with mitochondria. ${ }^{93}$ Since 1992, the drug is no longer available in the United States but can be purchased in Canada. ${ }^{93}$ Cantharidin should be applied to the pared wart and covered with a nonporous occlusive tape for 24 hours. A blister will form and heal in 1 to 2 weeks. ${ }^{83}$ This process should be repeated in 1 to 3 weeks. ${ }^{93}$ Cure rates have been reported to be as high as $80 \%$ for common, plantar and periungual warts. ${ }^{93}$ There is no pain from application of cantharidin. It does not usually cause scarring, although blister formation can be painful and an annular ring may occur around the treated wart. ${ }^{93}$ There have been no randomized, controlled trials to test the efficacy of cantharidin for the treatment of nongenital warts.

\section{Cryotherapy}

Cryotherapy is available for the treatment of verruca vulgaris in primary care and dermatology offices. It is considered a second-line therapy. ${ }^{1}$ The most commonly used cryogen is liquid nitrogen with a temperature of $-196^{\circ} \mathrm{C} .{ }^{20}$ The effect on wart clearance may be through necrotic destruction of HPV-infected keratinocytes or by inducing local inflammation that triggers an effective cell-mediated response. ${ }^{20} \mathrm{HPV}$ can itself survive and be stored in liquid nitrogen for research purposes; thus, the treatment does not kill the virus, and one should exercise precautions against both the spread of virus from patient to patient by contaminated cryoprobes or swabs and the contamination of liquid nitrogen reservoirs. ${ }^{98}$ Verruca-Freeze (CryoSurgery, Inc., Nashville, TN) or equivalents are now available over the counter; however, they only freeze tissue to $-70^{\circ} \mathrm{C}$ and do not freeze tissue as fast as liquid nitrogen. ${ }^{22,23}$ Adverse effects with cryotherapy can include hypopigmentation or hyperpigmentation (especially in dark skin), tendon and/or nerve damage when therapy is too aggressive, and annular recurrence around the treated wart if blistering is excessive. ${ }^{1}$ Patients with poor circulation should also be treated with caution. ${ }^{20}$

Cryotherapy techniques can vary in application mode, freeze times and intervals between treatments. Liquid nitrogen cryotherapy can be performed with a spray gun or cotton wool bud. Wart cure rates after 3 months with treatments every 2 weeks have been reported to be $47 \%$ for cotton wool bud and $44 \%$ for spray gun; this difference is not significant. ${ }^{93}$ Warts present for 6 months or less had a greater chance of clearing (84\%) within the 3 months compared with warts present for more than 6 months $(39 \%) .93$

Freeze times for warts are defined as traditional or aggressive. Traditionally, cryotherapy is applied until the wart has a $2 \mathrm{~mm}$ white halo around it. 1 An aggressive or longer freeze maintains a white halo for 5-20 seconds. ${ }^{1}$ In a comparison of traditional freeze versus 10 second freeze, the longer freeze was more effective than the traditional method, although the incidence of pain and blistering is significantly greater. ${ }^{99}$

In a study of a double freeze-thaw technique versus a single freeze technique, it was found that there was no significant difference for cure rates at 3 months in using either technique for hand warts, but the double freeze-thaw technique may have been more effective for plantar warts. ${ }^{100}$ Even with paring, callus formation over warts may serve as a thermal insulator and reduce the effect of cryotherapy to below that required to induce even minimal cell damage. ${ }^{100}$

In a study of the frequency of wart cryotherapy and the efficacy of cure at 1,2 or 3 week intervals, the percentage cured was related to the number of treatments but was independent of the interval between treatments. ${ }^{101}$ Optimal treatment may be every 2 weeks, as it achieves a faster cure without affecting department workload, especially for patients who may desire a quicker cure before a forthcoming event. 101

In an assessment of 16 cryotherapy trials, most compared different regimens instead of comparing cryotherapy to other treatments or placebo. ${ }^{18}$ There was no significant difference between cryotherapy versus other treatments or placebo in pooled data of two small trials. ${ }^{18}$ More recently, it was demonstrated that there was no significant difference in wart clearance at 3 to 6 months between cryotherapy (65\%) and salicylic acid $(62 \%) .102$

An aggressive cryotherapy (10 second) was significantly more effective ( $52 \%$ cure rate) than gentle cryotherapy (brief freeze) (31\% cure rate) when data from four trials were pooled. ${ }^{19}$ However, pain and blistering occurred in 64 of 100 (64\%) participants treated with the aggressive regimen compared with 44 of 100 (44\%) treated with the gentle regimen. ${ }^{19}$ The optimum number of treatments for warts on the hands and feet in a large population of adults and children was examined by only one trial that demonstrated no significant benefit to prolonging cryotherapy after 3 months (about four freeze treatments). ${ }^{19}$

The optimum treatment interval was examined in three trials. Long-term cure rates comparing 2, 3 and 4 week intervals were not significantly different. ${ }^{19}$ The frequency of pain and blistering was higher with shorter treatment intervals, but this may have been due to seeing participants sooner after treatment. $^{19}$ 
While most of these studies report moderate success, in the hands of some practitioners cryosurgery has been reported to be much more effective. Using local or regional anesthesia prior to treatment, aggressive surgical debulking followed by double freeze-thaw open spray cryosurgery resulted in an $83.5 \%$ complete clearance rate with a single treatment in a series of 514 plantar warts. The complete clearance rate rose to $92.5 \%$ when those treated two and three times were included. ${ }^{76}$ While this was a non-randomized, non-controlled series, the success rate is nonetheless impressive and may speak to the importance of the technique. Overall, evidence concerning the relative merits of cryotherapy compared with placebo and other simpler and safer treatments is inconclusive. ${ }^{19}$

\section{Hot Water}

Simple sequential treatment by immersion in hot water $\left(45^{\circ} \mathrm{C}\right.$ to $48^{\circ} \mathrm{C}$ ) has been reported to dramatically improve certain cases of cutaneous warts of the hands and feet. ${ }^{103,104}$

\section{Exothermic Patches}

Small patches containing chemicals that produce heat through oxidation upon exposure to air have been applied to warts with anecdotal success. ${ }^{105}$

\section{Ultrasound Hyperthermia}

Several early reports attempted to use ultrasonic therapy to locally heat warts with some success, but this treatment seems to have been largely abandoned. ${ }^{106-112}$

\section{Radiofrequency Ablation}

Localized heating with radiofrequency heat generators as well as surgical excision with radiofrequency electrosurgical knives have been used with moderate success. ${ }^{113,114}$

\section{Microwave Treatment}

In vitro treatment of excised warts by applying microwave energy has been shown to produce more HPV DNA damage than $\mathrm{CO}_{2}$ laser treatment, but there has been no reported clinical application of microwave treatment. ${ }^{115}$

\section{Infrared Coagulation}

Direct application of infrared contact coagulators has been reported as a cheaper, safer and more easily handled alternative to $\mathrm{CO}_{2}$ laser treatment. The instrument allows adjustable tissue necrosis without tissue adhesion and has yielded remissions with a $10.8 \%$ recurrence rate. ${ }^{116}$ In comparison to electrocoagulation, infrared coagulation produces similar outcomes. ${ }^{117}$

\section{Carbon Dioxide $\left(\mathrm{CO}_{2}\right)$ Laser}

The $\mathrm{CO}_{2}$ lasers emit infrared light $(10,600 \mathrm{~nm})$ that is absorbed by water. Nonselective thermal tissue destruction results. A focused $\mathrm{CO}_{2}$ laser beam can be used as a scalpel to excise the wart down to the subcutaneous tissue after which the base of the wart is vaporized by a defocused beam until a clean surgical field is obtained. ${ }^{118}$ Two case series described a $64 \%$ to $71 \%$ cure rate at 12 months. ${ }^{20}$ No randomized, controlled trials have been published on the efficacy of $\mathrm{CO}_{2}$ laser. ${ }^{102}$ Lost skin heals by secondary intention. ${ }^{114}$ This treatment may be useful for periungual and subungual warts that are recalcitrant to other treatments. ${ }^{20}$ It has also been found to be useful in immunosuppressed patients; ${ }^{119}$ however, four cases of hypertrophic scarring following $\mathrm{CO}_{2}$ laser treatment of plantar warts in cyclosporin-treated renal transplant patients have been reported. ${ }^{120}$ Adverse effects of this treatment in immunocompetent patients include postoperative pain, prolonged healing time, and scarring. ${ }^{83}$

In using any laser, hazards may be associated with the laser plume, including pulmonary and infectious hazards from released bacterial, fungal or viral organisms. HPV DNA has been demonstrated in $\mathrm{CO}_{2}$ laser vapor, as well as in the vapors from electrocoagulation. ${ }^{121-125}$

\section{Erbium:Yttrium/Aluminum/Garnet (Er:YAG) Laser}

The Er:YAG laser emits a shorter wavelength infrared radiation $(2940 \mathrm{~nm})$ that is absorbed 12 to 18 times more efficiently by water-containing superficial cutaneous tissues than is the $10,600 \mathrm{~nm}$ wavelengths emitted by the $\mathrm{CO}_{2}$ laser. ${ }^{126}$ The Er:YAG laser has a smaller zone of thermal damage, thereby allowing more precise thermal ablation with minimal scarring. Warts in a variety of locations have been successfully eliminated in $75 \%$ of patients after a single treatment, with a $25 \%$ relapse rate within 1 year after treatment. ${ }^{127}$ Approximately $14 \%$ of patients are non-responders. 128 Postoperative healing occurred after 7 to 10 days, but erythema that occurred in all patients required 2 months to subside. A potential safety feature of this laser is that HPV DNA has not been detected in the laser plume. ${ }^{129}$

\section{Neodymium:YAG (Nd:YAG) Laser}

The Nd:YAG laser's principal emission wavelength is at 1064 $\mathrm{nm}$, still in the infrared range. Hyperthermic treatment with this laser has been reported to cause remission with no recurrence in several case reports and case series. ${ }^{130,131}$ In biopsied tissues, pre- and post-treatment with either cryotherapy or Nd:YAG hyperthermic therapy, HPV DNA was reduced from $100 \%$ to $96 \%$ after cryotherapy and from $100 \%$ to $0 \%$ after laser treatment. ${ }^{132} \mathrm{Nd}$ :YAG laser light has been guided through fiberoptics in a flexible probe to successfully treat recurrent respiratory papillomatosis caused by HPV 6 and 11 in children. By combining this probe with a suction channel to remove smoke and pyrolysis products, an optimal field of view is maintained and a minimal load of potential infectious laser plume and toxic pyrolysis products is removed during the procedure. ${ }^{133} \mathrm{Nd}$ :YAG lasers are also utilized in therapeutic treatment of genital tract lesions and for cervical conization of early neoplasias involving HPV infections. 134,135

\section{Pulsed Dye Laser}

The mechanism of action of the pulsed dye laser is through selective microvascular destruction of dilated capillaries in 
the warts. This happens as a result of thermal damage occurring upon yellow light absorption $(585 \mathrm{~nm})$ by oxyhemoglobin. Thermal damage, removal of the blood supply, and a cell-mediated immune response are believed to contribute to wart healing. ${ }^{114}$ The treatment sensation has been compared to being snapped by a rubber band and is considered relatively painless. ${ }^{55}$ However, some patients do report severe intraoperative pain. ${ }^{136,137}$ As the vessels burst, purpura develops within minutes in the treated areas and takes 10 to 14 days to resolve as macrophages digest the residues. ${ }^{137}$ Pulsed dye laser causes minimal postoperative pain and completely heals in 2 to 4 weeks. ${ }^{114}$ It produces less pain and scarring than with $\mathrm{CO}_{2}$ laser treatment and has been used for facial warts and perianal warts in children. ${ }^{20,138,139}$

Pulse dye laser has been reported to result in complete remission in $48 \%$ to $95 \%$ of cases. ${ }^{102,137,140-147}$ One study found no statistically significant difference among cure rates between pulsed dye laser (66\%) compared to conventional cryotherapy or cantharidin therapy $(70 \%) .147$ It appears that warts in nonacral locations respond better than those on the hands, and plantar warts respond the least to this treatment. 137,147

\section{Potassium-Titanyl-Phosphate (KTP) Laser}

The KTP laser has been utilized in the treatment of recalcitrant cutaneous warts and when treated to complete clearance, no recurrence occurred. ${ }^{148}$

\section{Photodynamic Therapy}

Rather than using endogenous target absorbers (i.e., water for the $\mathrm{CO}_{2}$ laser and oxyhemoglobin for the $585 \mathrm{~nm}$ pulsed dye laser), photodynamic therapy uses light of a wavelength absorbed by specific photosensitizing molecules that are exogenously administered to the target tissue. ${ }^{149}$ One agent commonly used is 5-aminolaevulinic acid (ALA), which is a prodrug that stimulates porphyrin accumulation in the tissue. ${ }^{150,151}$ Porphyrins then act as the photosensitizing agent. When illuminated, the porphyrins induce a photooxidation cascade that damages the involved cells. The lights used range from lasers to photoemitting diodes to white lights that cover the porphyrin excitation peak. The ALA is applied topically as an ointment or cream and preferentially accumulates in the lesions. ${ }^{152}$

Photodynamic therapy has been applied to warts in sensitive mucosal tissues including venereal warts and cervical intraepithelial neoplasia (CIN) in the vulva, penis and urethra and to oral and respiratory tract papillomas. ${ }^{51,152-155}$ Generally, results are equivalent to or superior to other treatment modalities with the advantage that little, if any, scarring results. Additionally, the photosensitizers fluoresce which can assist in the pretreatment localization of lesions. ${ }^{8,156}$

Photodynamic therapy has also been used to treat common warts on the hand, flat warts and plantar warts. ${ }^{157-160}$ In the treatment of plantar warts, delivery of the ALA is performed after keratolysis with urea and salicylic acid and gentle curettage. ${ }^{161}$

\section{Virucidal Therapy}

Glutaraldehyde

Glutaraldehyde is virucidal and available as a $10 \%$ water miscible gel or alcohol solution. ${ }^{1}$ Application of glutaraldehyde is typically applied twice a day and can stain the skin brown, as well as cause contact sensitivity. ${ }^{1}$ Treatment has been reported to be as effective as with salicylic acid with cure rates over $70 \%{ }^{1}$ No randomized, controlled trials for glutaraldehyde treatment of warts have been published. ${ }^{19}$

\section{Formaldehyde}

Formaldehyde is also virucidal and works by disrupting the upper layer of epidermal cells and possibly damaging the virions. ${ }^{1}$ Available $0.7 \%$ gels or $3 \%$ solutions are used to soak pared plantar warts to speed resolution. ${ }^{20}$ Formaldehyde, widely used as a preservative in many products such as lotions and shampoos, can cause sensitization and should be avoided in patients with eczema and allergies. ${ }^{1}$

One controlled trial of formaldehyde wart treatment involved 192 participants with plantar warts. Cure rates ranged between $61 \%$ and $67 \%$ at 2 months but were not significantly different between the four treatment groups: $3 \%$ formalin, $3 \%$ formalin with paring, water (placebo) and sucrose tablets (placebo). ${ }^{19}$

\section{Formic Acid}

Formic acid is the chemical irritant found in the stings and bites of many hymenopteran insects, including bees and ants, and was first isolated from red ants, hence the name from the Latin for ant, formica. It is also the irritant in the leaves of stinging nettles. In a nonrandomized, placebo-controlled, open trial in 100 patients, a topical $85 \%$ formic acid/needle puncture technique resulted in a $92 \%$ complete clearance rate as compared with $6 \%$ in the placebo (water) group. ${ }^{162}$ The mechanism of action of this agent is not known. It may relate to the mode by which formaldehyde acts, or it may act in the series of caustic acids. With salicylic acid being the weakest, trichloroacetic acid being of medium strength, and bichloracetic acid being the strongest, the strength of formic acid lies between that of salicylic acid and trichloroacetic acid.

\section{Antiviral Drugs}

Cidofovir is a nucleoside analogue of deoxycytidine monophosphate that inhibits DNA synthesis, induces DNA fragmentation, reduces epithelialization and enhances excoriation. ${ }^{163-165}$ It has been used successfully in HIV-positive patients for the topical treatment of genital warts. ${ }^{166-170}$

A case has been reported in which a homosexual man with HIV had multiple extensive warts. When treated with oral antiretroviral therapy (didanosine, stavudine and efavirenz or abacavir), there was a nearly total regression of the viral warts 
along with a significant improvement in the patient's immune status. ${ }^{171}$

\section{Antimitotic Therapy \\ Bleomycin}

Bleomycin, an antibiotic derived from Streptomyces verticillus, is reserved for recalcitrant warts that have failed other types of treatment. $^{20}$ It selectively affects squamous cell and reticuloendothelial tissue. ${ }^{172}$ DNA and protein synthesis are inhibited, and apoptosis is triggered. Bleomycin is not thought to bind directly to HPV. ${ }^{93}$ Bleomycin causes acute tissue necrosis that may stimulate an immune response, as evidenced by the fact that it is less effective as a wart treatment in immunosuppressed renal transplant patients. ${ }^{22,23,173,174}$ Bleomycin treatment of warts results in significant systemic drug exposure and should not be used on pregnant women, children, immunosuppressed patients or patients with vascular disease. ${ }^{93,174}$ Adverse effects include injection pain and burning, erythema, swelling and pain within 24 to 72 hours after injection before a black thrombotic eschar forms. Raynaud's phenomenon is a definite concern in treated digits, and the nail may become dystrophic or be completely lost. ${ }^{93,175,176}$ Bleomycin may also cause lymphangitis and flagellate hyperpigmentation.1,177

A double-blind, placebo-controlled study of warts recalcitrant twice to conventional treatments compared one to two intralesional injections of bleomycin to injections of normal saline. Plantar warts (60\%), periungual warts (94\%) and warts elsewhere on the extremities (95\%) were cleared. ${ }^{178}$ The success of bleomycin treatment can be technique-dependent. ${ }^{179}$ Using a bifurcated needle has been reported to improve outcome. ${ }^{180,181}$ One study achieved a $92 \%$ cure rate of 258 warts with only one treatment of bleomycin using a technique of multiple wart punctures with a bifurcated needle. ${ }^{180}$ The bifurcated needle puncture technique required 0.001 units of bleomycin compared to 0.2 units injected intralesionally under the base of a wart. Only the soft epidermis comes in contact with the bleomycin avoiding dermal exposure. 180 Another technique is to apply the bleomycin solution by drops onto the wart and then prick the solution into the wart using a 28 -guage lancet needle. This has resulted in a $92 \%$ clearance rate. ${ }^{182}$ Others have used modified tattooing devices with some success. ${ }^{172}$

Five randomized, controlled trials have evaluated the effectiveness of bleomycin; ${ }^{102}$ however, it is difficult to compare the trials. ${ }^{19}$ Cure rates ranged from $16 \%$ to $94 \%$. Three trials demonstrated higher cure rates with bleomycin than with placebo, one showed no significant difference between bleomycin and placebo, and one showed higher cure rates with placebo than with bleomycin. Different concentrations of bleomycin also made no significant difference after 3 months. ${ }^{102}$

\section{Retinoids}

Epidermal growth and differentiation are disrupted by retinoids, so wart growth is affected. Retinoids are also potent immunomodulators. ${ }^{183}$ There is some evidence that retinoids can downregulate HPV transcription in affected cells as well. ${ }^{184,185}$ Retinoids can be administered topically or systemically. Treatment of warts with a tretinoin cream resulted in $85 \%$ clearance in a series of children as compared to $32 \%$ spontaneous clearance in controls. ${ }^{186}$ Eighty percent of children treated with daily etretinate orally for up to 3 months exhibited complete regression, with the remainder showing partial regression. ${ }^{187}$ Other trials and case reports have shown systemic retinoids, especially synthetic isotretinoin, to have an effect on a variety of warts, particularly genital warts. ${ }^{188-191}$ A great deal of interest has been expressed in the use of retinoids as a potential chemopreventive and/or therapy in HPV-related cervical cancer. ${ }^{192}$

\section{Podophyllin}

The rhizomes of the mayapple plant (Podophyllum peltatum) that grows throughout eastern and midwestern North America are the source of podophyllin resin, the crude alcohol extract containing podophyllotoxin, 4-demethylpodophyllotoxin, $\alpha$-peltatin and $\beta$-peltatin. ${ }^{193}$ The Penobscot Indians of the northeastern United States used poultices of mayapple for the treatment of warts. ${ }^{194}$ Physicians in New Orleans used podophyllin for the treatment of genital warts in the 1930s. ${ }^{195,196}$

Podophyllin resin has been used mostly in the treatment of anogenital warts. A 1990 study demonstrated a 41\% complete clearance rate for patients who received up to six weekly treatments for external genital warts, but only a $17 \%$ clearance at 3 months. ${ }^{197}$ Similarly, a 1991 study demonstrated a $45 \%$ clearance rate of anogenital warts at 3 months with $73 \%$ remaining clear at 9 months. This outcome was compared to a $23 \%$ clearance rate with subcutaneous interferon- $\alpha_{2 a}$ at 3 months with $77 \%$ remaining clear at 9 months. ${ }^{198}$ An advantage to podophyllin treatment is that it can be self-administered with greater patient convenience and cost effectiveness. 199

In studies conducted between 1969 and 1975, podophyllin treatment was shown to have an $81 \%$ cure rate for simple plantar warts (comparable to an $84 \%$ cure rate for a paint containing salicylic and lactic acids). ${ }^{97}$

Guidelines of the United States and the United Kingdom on the treatment of anogenital warts include podophyllin in their recommendations, ${ }^{20,27,29}$ but it has been shown that podophyllin resin is both less effective and less cost effective than purified podophyllotoxin, the active ingredient, and there is no evidence that podophyllin in combination with any other agent enhances clinical response. ${ }^{200-205}$ In addition, podophyllin preparations vary between batches and have been shown to have toxic side effects. ${ }^{203,204,206}$ In contrast, purified podophyllotoxin exhibits low clinical toxicity. 204,205 


\section{Podophyllotoxin}

Podophyllum hexandrum grows in the mountainous regions of India and contains a higher content of podophyllotoxin, the active component. ${ }^{207}$ Podophyllotoxin binds to microtubules and causes mitotic arrest in the metaphase of cell division. ${ }^{208}$ In a small (19 treatment, 19 control), double-blind, randomized clinical trial of self-administered podophyllotoxin solution versus vehicle in the treatment of genital warts, patients were instructed to administer $0.5 \%$ solution or vehicle at home twice daily for 3 consecutive days of each week for 4 weeks. ${ }^{209}$ At the end of the 4 week regimen, the treatment group experienced a $94.9 \%$ reduction in wart area and $84.1 \%$ reduction in wart count as opposed to $7.1 \%$ and $2.6 \%$ for the vehicle only placebo. This translates into 1.1 patients needed to treat before seeing a significant reduction in wart area due to treatment, and 1.2 patients for wart count. These are very impressive needed to treats; however, only $21 \%$ of patients remained free of warts 2 weeks after treatment, and all patients available for long-term follow-up experienced recurrences. Thus, the podophyllotoxin solution appears highly effective for short-term treatment of symptoms but does not provide a long-term cure.

In a more recent randomized comparison of external genital wart treatment with a weekly application of $20 \%$ podophyllin solution versus self-administered $0.5 \%$ podophyllotoxin cream twice daily for 3 days in weekly intervals, the total eradication of warts was $74 \%$ versus $94 \%$ respectively. ${ }^{210}$ The advantage of easy self-application of the podophyllotoxin cream makes this an appealing alternative for the treatment of external genital warts.

\section{Immunotherapy}

\section{Oral Zinc Sulphate}

Dietary zinc has profound effects on the human immune system, and deficiency leads to reduced immune capacity. ${ }^{211,212}$ Based on this, a placebo-controlled clinical trial was attempted using oral zinc sulphate $(10 \mathrm{mg} / \mathrm{kg}$ daily) to treat recalcitrant warts. Complete clearance was reported in $87 \%$ of the treatment group versus no clearance in the placebo group. ${ }^{213}$

\section{Contact Sensitizers}

The mechanism of action for topical immunotherapy with contact sensitizers is proposed to be a type IV hypersensitivity reaction. ${ }^{1}$ The immune response is purported to be directed against a complex of contact agent hapten bound to protein of viral or human origin that enhances wart regression. ${ }^{1}$ An effective topical immunotherapy contact sensitizer should ideally be readily available, able to sensitize at least $95 \%$ of the normal population, chemically stable, economical, free of significant adverse effects and rarely occurring in the human environment. ${ }^{214}$

In 1973, Lewis first reported immunotherapy using dinitrochlorobenzene (DNCB) for common warts. 215 Two randomized, controlled trials have compared DNCB to placebo with results demonstrating $80 \%$ clearance of warts with DNCB and 38\% clearance with placebo. ${ }^{56,102}$ DNCB is mutagenic, so it is no longer used in clinical settings. ${ }^{215}$

Diphencyprone (DCP), the standard sensitizer used for topical immunotherapy, is nonmutagenic and is available in acetone solution. ${ }^{215}$ It has a shelf life of 3-6 months at room temperature if stored in an amber glass bottle to prevent light degradation. ${ }^{215}$ Another nonmutagenic contact sensitizer, squaric acid dibutyl ester (SADBE), has been used in treatment of recalcitrant warts. SADBE is more expensive and less stable in solution than DCP.214,215

Buckley et al reviewed resistant hand and foot warts treated with DCP over 8 years. ${ }^{216}$ Patients were sensitized with a $2 \%$ DCP solution on the medial upper arm every 10 to 14 days until local erythema and vesiculation occurred. Treatment was repeated up to 3 times. Pared warts were then treated with stepwise concentrations of DCP: $0.01 \%, 0.05 \%, 0.1 \%$, $0.25 \%, 0.5 \%, 1.0 \%, 1.5 \%, 2.0 \%, 3.0 \%, 4.0 \%$ and $6.0 \%$. Plantar warts were treated with $2.0 \%$ and digital warts with $0.1 \%$ as initial concentrations. Treatments were applied every 1 to 4 weeks, and the DCP concentration was adjusted by the patient's response. At each visit, after questioning about adverse effects and degree of improvement, the concentration of DCP was increased by one step if there was no response. It was kept constant if there was an adequate response and was lowered by one step if severe blistering occurred. Forty-two of 48 individuals completed treatment and exhibited an $88 \%$ clearance rate. Adverse effects occurred in $56 \%$ of the 48 patients and included painful blistering near the wart, blistering at the sensitization site, pompholyx-like or more generalized eczematous eruption, influenza-like symptoms, vesiculation elsewhere due to passive transfer of DCP and inguinal adenopathy.

Patients with recalcitrant plantar, palmar, periungual and digital warts are candidates for DCP treatment. ${ }^{214}$ Compared to other treatments, DCP is less destructive, less costly, less time-consuming to perform, and can be used for the concurrent treatment of multiple warts. ${ }^{214}$ However, treatment should be limited to the clinical setting, and patients need sequential applications to ensure maximal outcome. ${ }^{214}$

\section{Intralesional Injection of Interferon}

For genital warts that are recurrent or recalcitrant to other treatments, intralesional injection of interferon- $\alpha$ has been tested in a randomized, double-blind, placebo-controlled, multicenter trial. Leukocytic interferon can both kill viruses and stimulate the immune system. The interferon or placebo was injected twice weekly for up to 8 weeks. Complete clearance was seen in $62 \%$ of interferon- $\alpha$ patients compared to $21 \%$ of placebo-treated patients. ${ }^{217}$ Intralesional interferon- $\alpha$ has also been used successfully in the treatment of recurrent oral warts in AIDS patients. ${ }^{218}$

Intralesional Injection of Mumps or Candida Antigen

Intralesional injection of mumps or Candida may be a 
treatment option for recalcitrant warts that have not resolved with other therapies. One trial compared the intralesional injection of one wart with Candida or mumps antigen to cryotherapy of all warts. ${ }^{219}$ Excluded were patients with prior allergic response to mumps or Candida antisera, pregnancy, HIV infection, iatrogenic immunosuppression, primary immunosuppression or any generalized dermatitis. An intradermal injection of $0.1 \mathrm{ml}$ of mumps and Candida antigen was placed in the right and left forearms, respectively. The amount of reaction was read after 48 to 72 hours. Based on the size of test reaction, the responder's largest wart was treated with an intralesional injection of mumps or Candida. Nonresponders and randomized immune responders received cryotherapy with a 1- to 2-mm halo of frozen tissue for 30 seconds using a double freeze-thaw technique. Treatments with cryotherapy and intralesional antigen injection were performed every 3 weeks until the warts completely cleared or for a total of three treatments. On follow-up, the response to the treatment (decrease in wart number and size) was assessed.

Of 115 patients, $30 \%$ were anergic to Candida and mumps antigen, and $70 \%$ had immunity to at least one of the antigens. The immune group was divided into $32 \%$ receiving cryotherapy, $56 \%$ receiving intralesional mumps antigen and $12 \%$ receiving intralesional Candida antigen. The anergic group included $82 \%$ of patients receiving cryotherapy and $18 \%$ who refused treatment. Complete wart clearance was achieved in $74 \%$ of immune individuals treated with mumps or Candida antigen immunotherapy compared to $55 \%$ treated with cryotherapy. Anergic patients treated with cryotherapy exhibited 58\% clearance. Seventy-eight percent of patients treated with Candida and mumps antigen immunotherapy had resolution of untreated warts in different anatomical locations. Six patients developed flu-like symptoms (fever, malaise and myalgia) within 12 hours of intralesional injection of antigen that lasted up to 24 hours. Symptoms were treated with nonsteroidal anti-inflammatories. The most common complaints were pain upon intralesional injection and pruritus within the first 24 hours.

It was concluded that immunotherapy should serve as first-line treatment for immune individuals with numerous $(>5)$ or large $(>1 \mathrm{~cm})$ warts and as an effective second-line treatment in immune individuals who are judged to have failed cryotherapy. ${ }^{219}$ The mechanism of action for this type of immunotherapy was proposed to be based on trauma and subsequent inflammatory reaction of the intralesional injection leading to an HPV-directed immunologic reaction. ${ }^{219,220}$

Another trial used the same method to assess immunotherapy by intralesional mumps or Candida antigens for recalcitrant warts in children who had previously been treated with liquid nitrogen and at least one other type of treatment. ${ }^{44}$ Children in the study $(\mathrm{n}=47)$ each had an average of 5.96 warts. Complete clearance was achieved in $47 \%$ of treated warts with an average of 3.78 treatments. Greater than $25 \%$ improvement of warts was seen in an additional $34 \%$ of the children treated. Sixty-eight (68\%) with multiple warts noted at least partial resolution of anatomically distinct, untreated warts. Fourteen children experienced $100 \%$ resolution of distant warts. Side effects included itching at the injection site in $50 \%$ of the children and $10 \%$ had edema or erythema. ${ }^{44}$ None reported severe pain or scarring. The initial skin test induration size of mumps and Candida antigen did not affect the clearance of the treated wart or distant wart resolution.

The lower response rate compared to the former study was thought to be due to the inclusion of only children with recalcitrant warts. Higher response rates may be expected in the initial treatment of children's warts. There may also be less immune response to skin test antigens in children as compared to adults. It was proposed that intralesional injection of mumps or Candida antigen be considered a first-line therapy in children with large or multiple warts and a second-line therapy in warts recalcitrant to standard therapies, particularly because of its high level of tolerability. ${ }^{44} \mathrm{~A}$ variety of adverse reactions, including delayed-type hypersensitivity reaction, has been reported with Candida antigen treatments. ${ }^{221}$

\section{5-Fluorouracil (5-FU)}

Fluorouracil has been used topically as an antiproliferative agent for warts. ${ }^{18,19}$ In one prospective placebo-controlled, single-blind, randomized trial, up to $70 \%$ of warts underwent complete response when treated with 5-FU combined with lidocaine to reduce pain and epinephrine to induce vasoconstriction in order to sustain high local drug concentrations. 222

\section{Cimetidine}

Daily doses of 20 to $40 \mathrm{mg} / \mathrm{kg}$ cimetidine, an H2-receptor antagonist, cleared up to $82 \%$ of recalcitrant warts in open label studies. ${ }^{223}$ Cimetidine is postulated to act as an immunomodulating agent at high doses by inhibiting suppressor T-cell function while increasing lymphocyte proliferation, thereby enhancing cell-mediated immune responses. 223,224 Others found insufficient evidence of efficacy in three small randomized, controlled trials between cimetidine and placebo. ${ }^{102}$

In a randomized, placebo-controlled, double-blind study of treating recalcitrant warts in adults with a 12 week course of cimetidine at $2400 \mathrm{mg} /$ day $(22-46 \mathrm{mg} / \mathrm{kg}$ daily) or placebo, the clearance rate of warts with cimetidine and placebo was $26 \%$ and $5 \%$, respectively (not significant; $P=0.085$ ). 223

Another double-blind, placebo-controlled study compared 12 weeks of treatment with cimetidine at $400 \mathrm{mg} 3$ times per day versus placebo in patients over 12-years-old. ${ }^{225}$ Wart clearance for the cimetidine group was $27 \%$ and $22 \%$ for placebo, which was not a statistically significant difference. The study investigators proposed a placebo effect for cimetidine. 
A third randomized, controlled trial used cimetidine in doses of 25 to $40 \mathrm{mg} / \mathrm{kg}$ daily versus placebo in women and children ages 4 to 39 years old. 226 The cure rate of warts was $32 \%$ with cimetidine and $30.9 \%$ in the placebo group, again not a statistically significant difference.

By contrast, in a retrospective assessment of 216 patients who were administered oral cimetidine therapy for verrucae plantaris, it was concluded that cimetidine is a safe, effective lone treatment modality for verrucae in all age groups. ${ }^{227}$

\section{Levamisole}

Levamisole is another immunomodulating drug that has been used effectively in the treatment of flat and common warts with moderate success. ${ }^{228}$

\section{Imiquimod}

Imiquimod $5 \%$ cream is an immunomodulator that may stimulate cytokines, including interferon- $\alpha$, interleukin-1, interleukin-6, tumor necrosis factor- $\alpha$, granulocyte-macrophage colony-stimulating factor and granulocyte colony-stimulating factor. ${ }^{83}$ Absorption of imiquimod through intact skin is minimal. ${ }^{1}$ Its use in the treatment of external anogenital warts was approved by the United States Federal Drug Administration in 1997, and it has more recently been approved for the treatment of nonhyperkeratotic, nonhypertrophic actinic keratoses and superficial basal cell carcinomas.

The use of imiquimod for the treatment of non-genital warts has not been formally assessed by a randomized, controlled trial. However, in an open label, uncontrolled study using imiquimod 5\% cream to treat common cutaneous warts, patients applied imiquimod $5 \%$ cream to the warts once a day for five successive days in a week and washed it off in the morning with soap and water. ${ }^{229}$ The patients continued this regimen for up to 16 weeks or until the warts were no longer visible. Total clearance of warts occurred in $30 \%$ of patients; $26 \%$ of patients had a $>50 \%$ reduction in wart size. A breakdown of wart clearance by location included trunk $(75 \%)$, face $(70 \%)$, hands (60\%), and feet (37.5\%). Follow-up was performed at 32 weeks, at which time no warts had recurred in the treated areas. An adverse local inflammatory reaction was reported in $31 \%$ of patients, but it was considered mild and transient. Other side effects were erosions, pruritus, bacterial infection, fever and scarring. Disadvantages of using imiquimod $5 \%$ cream were the high cost and the length of average treatment ( 9.5 weeks). Others have reported effective treatment of recalcitrant plantar, periungual and subungual, as well as anogenital warts by applying imiquimod cream over 12 weeks with no evident recurrence or side effects. ${ }^{230-235}$ Application of imiquimod cream following laser treatment of anogenital warts, beginning when wound healing had completed, proved effective in reducing recurrences. ${ }^{236}$ Advantages of using imiquimod 5\% cream in children included less pain and trauma than other treatments, such as salicylic acid, cryotherapy or laser. ${ }^{229}$ Among adults, the costs and pain of office-based procedures can be avoided when the imiquimod cream is self-applied. 237

\section{Bacillus Calmette-Guérin Therapy}

Intravesical instillation of viable bacillus Calumette-Guérin is a standard adjuvant treatment for recurrent superficial bladder cancer. ${ }^{238}$ The mode of action is based on stimulation of the local immune response. ${ }^{239,240}$ The immune responses to malignant and virally transformed cells are similar. ${ }^{241,242}$ Therefore, topical bacillus Calumette-Guérin treatment has been attempted in the treatment of venereal warts. Complete response has been achieved in $60 \%$ to $92 \%$ of patients treated after 1 or 2 cycles, and they remained disease free after 6 to 9 months. Eight percent to 30\% were unresponsive..$^{243-245}$

\section{Vaccines}

Early attempts at vaccination for the treatment of persistent or recurrent anal and perianal venereal warts utilized an autologous vaccine prepared from wart extracts obtained from individual patients that was injected subcutaneously weekly for six weeks. Excellent results were obtained in $84 \%$ of patients with only $5 \%$ not responding, and all complete remissions that were followed remained disease free for an average of 46 months. ${ }^{246}$

Today, the development of new strain-specific HPV vaccines against venereal warts is progressing rapidly. ${ }^{247-252}$ Clinical trials of vaccines to prevent acquisition of oncogenic HPV are proving to be both safe and effective. ${ }^{30}$ Through recombinant genetic engineering techniques, the major viral capsid L1 protein is expressed on the surface of another organism (such as a yeast cell or baculovirus) so that the organism appears like a non-infectious HPV virus-like particle (VLP). ${ }^{253}$ The purified recombinant $\mathrm{L} 1$ capsid proteins can also self-assemble into highly immunogenic VLPs. ${ }^{254}$ VLP vaccines designed to express HPV 11, 16 or 18 L1 protein are highly immunogenic. ${ }^{255-259}$ Studies using HPV 16 L1 VLP vaccine to immunize at-risk women have proven effective. ${ }^{254,260}$ Seventeen to 18 months after vaccination, none exhibited a cervical intraepithelial neoplasia grade 3 (CIN/3) caused by HPV 16 infection. A bivalent HPV 16, 18 L1 VLP vaccine has proven effective in preventing incident and persistent cervical infections with HPV 16 and HPV 18 and associated cytological abnormalities and lesions. ${ }^{261}$ In a randomized, double-blind, placebo-controlled, multicenter, phase II efficacy trial, a quadrivalent $\operatorname{HPV}(6,11,16$ and 18) L1 VLP vaccine provided a $90 \%$ reduction in the incidence of persistent infection or disease after 36 months as compared to placebo. ${ }^{36,37}$ While these vaccines hold great promise for the prevention of nascent viral warts, they are thought less likely to be of therapeutic value. ${ }^{39}$

With the ongoing development of these new vaccines, a variety of questions will need to be addressed before an HPV vaccination program can be started. ${ }^{262-265}$ One major hurdle will be to promote an effective universal program to immunize preadolescents (10 to 13-year-olds who are likely 
to be HPV negative) with these vaccines ${ }^{36,266-268}$ in contrast to vaccination as a part of a HPV screening program in adults. ${ }^{269-273}$ Substantial barriers to HPV vaccine acceptance by parents and adolescents will have to be overcome in addition to the common barriers to immunizations in general.250,274,275 Questions will have to be answered as to whether to promote the vaccine as a cancer preventive or a sexually transmitted disease preventive measure. ${ }^{276}$ In addition to education during clinic visits, tailored multi-media campaigns on HPV can be useful. ${ }^{277}$ To date, no vaccines have been engineered against the HPV types that cause common warts.

\section{Combination Therapies}

Due to the frustrating resilience and recurrence of many wart cases, attempts are commonly made to combine therapies. In a cross-sectional survey of treatment choices for anogenital warts in nine genitourinary medical clinics across the United Kingdom, about $11 \%$ of all single treatments involved a combination of two or more agents. ${ }^{278}$ Treatment decisions were based upon the number of warts, site, morphology, patient preference for treatment and co-existing medical conditions (e.g., immunodeficiency, pregnancy). It was concluded that there is little evidence to support combination therapy and that more information is needed on complications and efficacy before recommendations can be made. A sample of combination therapy outcomes in other studies follows:

\section{5\% Imiquimod + Salicylic Acid}

Plantar warts have been successfully treated using 5\% imiquimod cream under occlusion with a $40 \%$ salicylic acid pad. It was thought that the salicylic acid facilitated delivery of the imiquimod through the thick skin surface on the plantar surface. ${ }^{279,280}$

\section{Cryotherapy $+5 \%$ Imiquimod + Salicylic Acid}

A $50 \%$ to $100 \%$ clearance rate after 6 to 9 weeks has been reported after treatment with liquid nitrogen cryotherapy followed by $17 \%$ salicylic acid at bed time and $5 \%$ imiquimod each morning. ${ }^{281}$

\section{5-FU + Salicylic Acid}

In an uncontrolled, retrospective study, twice daily topical application of 5 -FU $(0.5 \%$ or $5.0 \%)$ was combined with salicylic acid $(17 \%$ or $40 \%)$ to treat plantar warts with complete clinical resolution in all patients. ${ }^{282}$ Recurrence occurred in $15 \%$ of lesions, but these subsequently resolved upon repeated treatment.

\section{Systemic Interferon- $\alpha_{2 b}+$ Isotretinoin}

In the treatment of venereal warts, statistically significant higher remission rates and lower recurrence rates with shorter treatment durations were achieved with systemic interferon- $\alpha_{2 b}$ plus isotretinoin versus the retinoid alone. ${ }^{283-286}$ This combination therapy has also been used to successfully treat cases of epidermodysplasia verruciformis, a genetically determined susceptibility to widespread and persistent HPV infection. ${ }^{287,288}$
Intralesional Interferon- $\alpha_{2 b}+$ Podophyllin Resin

In a medium sized (49 combination therapy, 48 monotherapy) randomized trial, patients received either a combination intralesional interferon- $\alpha_{2 b}\left(1.5 \times 10^{6} \mathrm{IU}\right)$ plus topical $25 \%$ podophyllin resin or topical podophyllin resin alone. ${ }^{289}$ Complete clearance of treated warts was seen in $67 \%$ of those receiving combination therapy versus $42 \%$ in those receiving monotherapy with podophyllin. Maximal response was exhibited after 2 weeks of therapy. Additionally, 18\% of warts persisted despite either treatment, and after 11 weeks of follow-up in those who had seen complete clearance, a $67 \%$ recurrence occurred in the combination arm, and $65 \%$ recurrence was seen in the podophyllin-only arm.

\section{Podophyllin + Vidarabine}

CIN is considered to be the precursor to cervical cancer. ${ }^{290}$ The co-application of vidarabine and podophyllin over six treatments resulted in the cytological and histological regression of lesions and the disappearance of HPV 16 and 18 DNA in 17 of $21(81 \%)$ of women with CIN I-II. ${ }^{291}$ Vidarabine is a DNA polymerase inhibitor that suppresses HPV gene expression in immortalized human cervical keratinocytes and cervical cancer cell lines in vitro.

\section{Cryotherapy + Podophyllotoxin}

In the treatment of anogenital warts in the United Kingdom, a combination of cryotherapy and podophyllotoxin is the most common first line treatment, regardless of site. ${ }^{278}$

\section{Er:YAG + Podophyllotoxin}

Recalcitrant palmoplantar warts have been treated with an ablative Er:YAG laser followed by $0.5 \%$ podophyllotoxin solution after wound healing to yield an $88.6 \%$ complete response rate with a $5.7 \%$ relapse rate. ${ }^{128}$

\section{Pulsed Dye Laser + Intralesional Bleomycin}

A pulsed dye laser has been used to pretreat or "prepare" recalcitrant warts immediately prior to intralesional bleomycin injection to help assure basal drug delivery. ${ }^{292}$ This treatment resulted in $100 \%$ clearance in immunocompetent patients and $89 \%$ clearance in subjects on long-term immunosuppressant drugs.

\section{Photoselective Dye Laser + Photosensitizer for Photodynamic Therapy}

In a sizable comparison trial, 81\% (91/112) of warts were cured in an average of 3.34 sessions by photoselective laser destruction using a pulsed dye laser alone. Ninety-six percent $(73 / 76)$ of warts were cured in 2.54 sessions using photodynamic therapy with aminolevulinic acid-induced protoporphyrin as a photosensitizer, 293 and $100 \%(86 / 86)$ of warts were cured when the therapeutic modalities were combined. 294 Warts in a variety of locations were treated. These cure rates are very promising, but no information on recurrence was provided. 
Combined Antigen Injection

Injection of a combination of Candida albicans, mumps and Trichophyton has been shown to be more effective than and as safe as single antigen injection in the treatment of cutaneous warts. ${ }^{295}$

\section{Cimetidine + Levamisole}

It has been reported that a treatment with combined cimetidine and levamisole is approximately twice as effective as cimetidine alone in the treatment of recalcitrant warts. 296,297

\section{Electrocautery + Cidofovir}

In a series of HIV patients with genital warts, surgical treatment by electrocautery resulted in a $93 \%$ clearance rate but a $74 \%$ relapse rate. Topical $1 \%$ cidofovir gel resulted in a $76 \%$ clearance rate with a $35 \%$ relapse rate. Using electrocautery followed by cidofovir gel application, the clearance rate was $100 \%$ with $27 \%$ relapse. .298

\section{Antiretroviral Regimen + Protease Inhibitor}

In HIV patients with recalcitrant hand warts, resolution has been observed when antiretroviral nucleoside analogue reverse transcriptase inhibitors [azidothymidine (AZT, zidovudine), dideoxyinosine (ddI, didanosine) dideoxycytidine (ddC, zalcitabine), (-)2',3'-dideoxy, 3'-thiacytidine (3TC, lamivudine), 2',3'-didehydro-3'-deoxythymidine (d4T, stavudine)] or non-nucleoside reverse transcriptase inhibitor (nevirapine, loviride, delavirdine) drug therapies were combined with potent protease inhibitors (i.e., ritonavir, indinavir and/or saquinavir). ${ }^{299,300}$ For facial warts in HIV patients, combined reverse transcriptase inhibitors and protease inhibitors have been used in addition to ablative treatment with a pulsed dye laser with good results. ${ }^{301}$

\section{Conclusion}

As can be seen, an enormous variety of wart treatment approaches have been attempted. Choosing the best wart treatment from this armamentarium can be difficult. Recalcitrant warts that have been present for over 6 months are more resistant to treatment than warts present for less than 6 months. Remission and recurrence can seem unpredictable. Invasive methods are often painful and require long recovery periods. Topical management is usually dependent on patient compliance and requires long application periods.

High quality randomized, controlled trials upon which to base evidence-based decisions are not available for most treatments, so they are not considered in official treatment guidelines. The highest quality of clinical evidence for monotherapies exists for cryotherapy (A, I), followed by photodynamic therapy (B, I), salicylic acid, bleomycin and retinoids $(\mathrm{B}, \mathrm{II})$, formaldehyde $(\mathrm{C}, \mathrm{II})$, thermocautery and glutaraldehyde (C, III), chemical cautery, $\mathrm{CO}_{2}$ laser, pulsed dye laser and topical sensitization (C, IV), and cimetidine (D, I). ${ }^{27}$ Official recommendations for treatment vary with site and type of wart. ${ }^{27}$ However, review of the literature suggests much higher success rates with less widely tested approaches and combination therapies.

Future research is needed to find a superior treatment of viral warts. This research should focus on the development of a specific antiviral therapy for HPV. The most exciting and promising treatments that are appearing on the horizon are the type-specific HPV vaccines. While current research is focused on oncogenic HPV, the same technologies could be applied to those HPV types that cause the more benign cutaneous warts. In the meantime, in future studies of verrucae, regardless of treatment approach it is prudent to consider the duration of each lesion, previous types of therapy and wart subtype, and to match patients by age, wart number, subtype and duration. ${ }^{147}$

It is of paramount importance when choosing from the armamentarium of wart treatments that the therapy be tailored to meet the needs of the patient and healthcare provider. In practice, the treatment of warts is likely to require an individualized approach and usually requires more than one therapeutic modality to achieve complete resolution. The management of warts depends on the age of the patient, the site of infection, the size, number and types of warts involved, the patient's immunological status, treatment availability and cost, and the patient's desire for therapy and ability to adhere to the treatment regimen. For children, it is desirous to have an effective and painless treatment that shows rapid results. Until the ultimate wart treatment is discovered, the patient must be properly educated about HPV viral etiology and specific treatment expectations to avoid frustration for the patient and healthcare provider.

\section{Acknowledgments}

The author thanks Marshfield Clinic Research Foundation for its support through the services of Graig Eldred, Alice Stargardt and Linda Weis in the preparation of this manuscript.

\section{References}

1. Leman JA, Benton EC. Verrucas. Guidelines for management. Am J Clin Dermatol 2000;1:143-149.

2. Ciconte A, Campbell J, Tabrizi S, Garland S, Marks R. Warts are not merely blemishes on the skin: A study on the morbidity associated with having viral cutaneous warts. Australas J Dermatol 2003;44:169-173.

3. Bosch FX, de Sanjose S. Chapter 1: Human papillomavirus and cervical cancer - burden and assessment of causality. J Natl Cancer Inst Monogr 2003;(31):3-13.

4. Gunter J. Genital and perianal warts: new treatment opportunities for human papillomavirus infection. Am J Obstet Gynecol 2003;189:S3-S11.

5. Baseman JG, Koutsky LA. The epidemiology of human papillomavirus infections. J Clin Virol 2005;32(Suppl 1):S16-S24.

6. Bosch FX, Lorincz A, Munoz N, Meijer CJ, Shah KV. The causal relation between human papillomavirus and cervical cancer. J Clin Pathol 2002;55:244-265.

7. Walboomers JM, Jacobs MV, Manos MM, Bosch FX, Kummer JA, Shah KV, Snijders PJ, Peto J, Meijer CJ, Munoz N. Human papillomavirus is a necessary cause of invasive cervical cancer worldwide. J Pathol 1999;189:12-19. 
8. Frimberger D, Schneede P, Hungerhuber E, Sroka R, Zaak D, Siebels M, Hofstetter A. Autofluorescence and 5 -aminolevulinic acid induced fluorescence diagnosis of penile carcinoma - new techniques to monitor Nd:YAG laser therapy. Urol Res 2002;30:295-300.

9. Bragg JW, Ratner D. Human papillomavirus type 2 in a squamous cell carcinoma of the finger. Dermatol Surg 2003;29:766-768.

10. Herrero R. Chapter 7: Human papillomavirus and cancer of the upper aerodigestive tract. J Natl Cancer Inst Monogr 2003;(31):47-51.

11. Pfister H. Chapter 8: Human papillomavirus and skin cancer. J Natl Cancer Inst Monogr 2003;(31):52-56.

12. Gillison ML, Shah KV. Chapter 9: Role of mucosal human papillomavirus in nongenital cancers. J Natl Cancer Inst Monogr 2003;(31):57-65.

13. Chen YC, Chen JH, Richard K, Chen PY, Christiani DC. Lung adenocarcinoma and human papillomavirus infection. Cancer 2004;101:1428-1436.

14. Hama N, Ohtsuka T, Yamazaki S. Squamous cell carcinoma of the penis in a man with a human papilloma virus 31 infection. J Dermatol 2005;32:581-584.

15. Schiffman M, Herrero R, Desalle R, Hildesheim A, Wacholder S, Rodriguez AC, Bratti MC, Sherman ME, Morales J, Guillen D, Alfaro M, Hutchinson M, Wright TC, Solomon D, Chen Z, Schussler J, Castle PE, Burk RD. The carcinogenicity of human papillomavirus types reflects viral evolution. Virology 2005;337:76-84.

16. Akgul B, Pfefferle R, Marcuzzi GP, Zigrino P, Krieg T, Pfister $\mathrm{H}$, Mauch C. Expression of matrix metalloproteinase (MMP)-2, MMP-9, MMP-13, and MT1-MMP in skin tumors of human papillomavirus type 8 transgenic mice. Exp Dermatol 2006; 15:35-42.

17. Katori H, Nozawa A, Tsukuda M. Increased expression of matrix metalloproteinase-2 and 9 and human papilloma virus infection are associated with malignant transformation of sinonasal inverted papilloma. J Surg Oncol 2006;93:80-85.

18. Gibbs S, Harvey I, Sterling J, Stark R. Local treatments for cutaneous warts: systematic review. BMJ 2002;325:461.

19. Gibbs S, Harvey I, Sterling JC, Stark R. Local treatments for cutaneous warts. Cochrane Database Syst Rev 2003;(3):CD001781.

20. Sterling JC, Handfield-Jones S, Hudson PM; British Association of Dermatologists. Guidelines for the management of cutaneous warts. Br J Dermatol 2001;144:4-11.

21. Chow KM. Physicians need more evidence on treatments of warts. Am Fam Physician 2003;68:1714.

22. Stulberg DL, Hutchinson AG. Molluscum contagiosum and warts. Am Fam Physician 2003;67:1233-1240.

23. Stulberg DL, Hutchinson AG. Physicians need more evidence on treatments of warts: in reply. Am Fam Physician. 2003;68:1714, 1716. Available at: http://www.aafp.org/afp/20031101/letters.html. Accessed May 10, 2006.

24. Fox PA, Tung MY. Human papillomavirus: burden of illness and treatment cost considerations. Am J Clin Dermatol 2005;6:365-381.

25. Drake LA, Ceilley RI, Cornelison RL, Dobes WL, Dorner W, Goltz RW, Lewis CW, Salasche SJ, Turner ML, Lowery BJ, Shama SK, Androphy EJ, Galen WK, Heaton CL, Lynch PJ, Chanco Turner ML. Guidelines of care for warts: human papillomavirus. Committee on Guidelines of Care. J Am Acad Dermatol 1995;32:98-103.

26. Micali G, Dall'Oglio F, Nasca MR, Tedeschi A. Management of cutaneous warts: an evidence-based approach. Am J Clin Dermatol 2004;5:311-317.
27. Agency for Healthcare Research and Quality. Guideline for the management of cutaneous warts. National Guideline Clearinghouse. Available at: http://www.guideline.gov/summary/summary.aspx?doc_id $=6$ $628 \& \mathrm{nbr}=004172 \&$ string $=$ Cutaneous + AND + warts. Accessed May 10, 2006.

28. Agency for Healthcare Research and Quality. 2002 national guideline for the management of anogenital warts. National Guideline Clearinghouse. Available at: http://www.guideline.gov/summary/summary.aspx?doc_id=3 046. Accessed December 13, 2005.

29. Bandolier. Genital wart treatments. Available at: http://www.jr2.ox.ac.uk/bandolier/band82/b82-3.html. Accessed December 6, 2005.

30. Rivera A, Tyring SK. Therapy of cutaneous human Papillomavirus infections. Dermatol Ther 2004;17:441-448.

31. Kirnbauer R, Lenz P, Okun MM. Human Papillomavirus. In: Bolognia J, Jorizzo J, Rapini R, eds. Dermatology. 1st ed. London: Mosby; 2003:1217-1233.

32. Schiffman M, Kjaer SK. Chapter 2: Natural history of anogenital human papillomavirus infection and neoplasia. J Natl Cancer Inst Monogr 2003;(31):14-19.

33. de Villiers EM, Fauquet C, Broker TR, Bernard HU, zur Hausen H. Classification of papillomaviruses. Virology 2004;324:17-27.

34. Brotzman GL. Evaluating the impact of HPV-related diseases Cervical cancer and genital warts. J Fam Pract 2005;54(7 Suppl):S3-9.

35. Gravitt PE, Jamshidi R. Diagnosis and management of oncogenic cervical human papillomavirus infection. Infect Dis Clin North Am 2005;19:439-458.

36. Villa LL. Prophylactic HPV vaccines: Reducing the burden of HPV-related diseases. Vaccine 2005; [Epub ahead of print].

37. Villa LL, Costa RL, Petta CA, Andrade RP, Ault KA, Giuliano AR, Wheeler CM, Koutsky LA, Malm C, Lehtinen M, Skjeldestad FE, Olsson SE, Steinwall M, Brown DR, Kurman RJ, Ronnett BM, Stoler MH, Ferenczy A, Harper DM, Tamms GM, Yu J, Lupinacci L, Railkar R, Taddeo FJ, Jansen KU, Esser MT, Sings HL, Saah AJ, Barr E. Prophylactic quadrivalent human papillomavirus (types 6, 11, 16, and 18) L1 virus-like particle vaccine in young women: a randomised double-blind placebo-controlled multicentre phase II efficacy trial. Lancet Oncol 2005;6:271-278.

38. Mendez F, Munoz N, Posso H, Molano M, Moreno V, van den Brule AJ, Ronderos M, Meijer C, Munoz A; Instituto Nacional de Cancerologia Human Papillomavirus Study Group. Cervical coinfection with human papillomavirus (HPV) types and possible implications for the prevention of cervical cancer by HPV vaccines. J Infect Dis 2005; 192:1158-1165.

39. Vandepapeliere P, Barrasso R, Meijer CJ, Walboomers JM, Wettendorff M, Stanberry LR, Lacey CJ. Randomized controlled trial of an adjuvanted human papillomavirus (HPV) type 6 L2E7 vaccine: infection of external anogenital warts with multiple HPV types and failure of therapeutic vaccination. J Infect Dis 2005;192:2099-2107.

40. Elbasha EH, Galvani AP. Vaccination against multiple HPV types. Math Biosci 2005;197:88-117.

41. Goncalves MA, Donadi EA. Immune cellular response to HPV: current concepts. Braz J Infect Dis 2004;8:1-9.

42. Ho GY, Studentsov YY, Bierman R, Burk RD. Natural history of human papillomavirus type 16 virus-like particle antibodies in young women. Cancer Epidemiol Biomarkers Prev 2004;13:110-116. 
43. Rintala MA, Grenman SE, Jarvenkyla ME, Syrjanen KJ, Syrjanen SM. High-risk types of human papillomavirus (HPV) DNA in oral and genital mucosa of infants during their first 3 years of life: experience from the Finnish HPV Family Study. Clin Infect Dis 2005;41:1728-1733.

44. Clifton MM, Johnson SM, Roberson PK, Kincannon J, Horn TD. Immunotherapy for recalcitrant warts in children using intralesional mumps or Candida antigens. Pediatr Dermatol 2003;20:268-271.

45. Bellew SG, Quartarolo N, Janniger CK. Childhood warts: an update. Cutis 2004;73:379-384.

46. Smolinski KN, Yan AC. How and when to treat molluscum contagiosum and warts in children. Pediatr Ann 2005;34:211-221.

47. Massing AM, Epstein WL. Natural history of warts. A two-year study. Arch Dermatol 1963;87:306-310.

48. Allen AL, Siegfried EC. The natural history of condyloma in children. J Am Acad Dermatol 1998;39:951-955.

49. Yesudian PD, Parslew RA. Treatment of recalcitrant plantar warts with imiquimod. J Dermatolog Treat 2002;13:31-33.

50. Tosti A, Piraccini BM. Nail disorders. In: Bolognia, J, Jorizzo J, Rapini R, eds. Dermatology. 1st ed. London: Mosby; 2003:1061-1078.

51. Kimberlin DW. Current status of antiviral therapy for juvenile-onset recurrent respiratory papillomatosis. Antiviral Res 2004;63:141-151.

52. Madinier I, Monteil RA. Human papillomaviruses in oral epithelial lesions. Comparative study between histopathology and immunohistochemistry in routine diagnosis. J Biol Buccale 1987;15:105-110.

53. Terai M, Takagi M, Matsukura T, Sata T. Oral wart associated with human papillomavirus type 2. J Oral Pathol Med 1999;28:137-140.

54. Lilly EA, Cameron JE, Shetty KV, Leigh JE, Hager S, McNulty KM, Cheeks C, Hagensee ME, Fidel PL Jr. Lack of evidence for local immune activity in oral hairy leukoplakia and oral wart lesions. Oral Microbiol Immunol 2005;20:154-162.

55. van Brederode RL, Engel ED. Combined cryotherapy/70\% salicylic acid treatment for plantar verrucae. J Foot Ankle Surg 2001;40:36-41.

56. Kuykendall-Ivy TD, Johnson SM. Evidence-based review of management of nongenital cutaneous warts. Cutis 2003;71:213-222.

57. Lowry DR, Androphy EJ. Warts. In: Freedberg IM, Eisen AZ, Klaus W, Austen KF, Goldsmith LA, Katz SI, eds. Fitzpatrick's dermatology in general medicine, vol. 2. 6th ed. New York: McGraw-Hill Inc;2003. 2119-2131.

58. Bolton RA. Nongenital warts: classification and treatment options. Am Fam Physician 1991;43:2049-2056.

59. Sanclemente G, Gill DK. Human papillomavirus molecular biology and pathogenesis. J Eur Acad Dermatol Venereol 2002;16:231-240.

60. Johnson RF, Barber TX. Hypnosis, suggestions, and warts: an experimental investigation implicating the importance of "believed-in efficacy". Am J Clin Hypn 1978;20:165-174.

61. Straatmeyer AJ, Rhodes NR. Condylomata acuminata: results of treatment using hypnosis. J Am Acad Dermatol 1983;9:434-436.

62. Spanos NP, Williams V, Gwynn MI. Effects of hypnotic, placebo, and salicylic acid treatments on wart regression. Psychosom Med 1990;52:109-114.

63. Ewin DM. Hypnotherapy for warts (verruca vulgaris): 41 consecutive cases with 33 cures. Am J Clin Hypn 1992;35:1-10.

64. Meineke V, Reichrath J, Reinhold U, Tilgen W. Verrucae vulgares in children: successful simulated X-ray treatment (a suggestion-based therapy). Dermatology 2002;204:287-289.

65. Ferreira JB, Duncan BR. Biofeedback-assisted hypnotherapy for warts in an adult with developmental disabilities. Altern Ther Health Med 2002;8:144,140-142.
66. Goldstein RH. Successful repeated hypnotic treatment of warts in the same individual: a case report. Am J Clin Hypn 2005;47:259-264.

67. Bakke AC, Purtzer MZ, Newton P. The effect of hypnotic-guided imagery on psychological well-being and immune function in patients with prior breast cancer. J Psychosom Res 2002;53:1131-1137.

68. Gruzelier JH. A review of the impact of hypnosis, relaxation, guided imagery and individual differences on aspects of immunity and health. Stress 2002;5:147-163.

69. Wood GJ, Bughi S, Morrison J, Tanavoli S, Tanavoli S, Zadeh HH. Hypnosis, differential expression of cytokines by T-cell subsets, and the hypothalamo-pituitary-adrenal axis. Am J Clin Hypn 2003;45:179-196.

70. Weber ND, Andersen DO, North JA, Murray BK, Lawson LD, Hughes BG. In vitro virucidal effects of Allium sativum (garlic) extract and compounds. Planta Med 1992;58:417-423.

71. Seki T, Tsuji K, Hayato Y, Moritomo T, Ariga T. Garlic and onion oils inhibit proliferation and induce differentiation of HL-60 cells. Cancer Lett 2000;160:29-35.

72. Dehghani F, Merat A, Panjehshahin MR, Handjani F. Healing effect of garlic extract on warts and corns. Int J Dermatol 2005;44:612-615.

73. Litt JZ. Don't excise-exorcise. Treatment for subungual and periungual warts. Cutis 1978;22:673-676.

74. Focht DR 3rd, Spicer C, Fairchok MP. The efficacy of duct tape vs cryotherapy in the treatment of verruca vulgaris (the common wart). Arch Pediatr Adolesc Med 2002;156:971-974.

75. Boyd AS, Neldner KH. The isomorphic response of Koebner. Int J Dermatol 1990;29:401-410.

76. Buckley D. Cryosurgery treatment of plantar warts. Ir Med J 2000;93:140-143.

77. Soroko YT, Repking MC, Clemment JA, Mitchell PL, Berg L. Treatment of plantar verrucae using $2 \%$ sodium salicylate iontophoresis. Phys Ther 2002;82:1184-1191.

78. Weiss G, Shemer A, Trau H. The Koebner phenomenon: review of the literature. J Eur Acad Dermatol Venereol 2002;16:241-248.

79. Vickers CF. Treatment of plantar warts in children. Br Med J 1961;5254:743-745.

80. Pringle WM, Helms DC. Treatment of plantar warts by blunt dissection. Arch Dermatol 1973;108:79-82.

81. Baruch K. Blunt dissection for the treatment of plantar verrucae. Cutis 1990;46:145-147, 151-152.

82. Matsumoto Y, Adachi A, Banno S, Hayashi Y, Ogiyama Y, Ohashi M. Prominent hyperkeratotic plantar and palmar warts. Cutis 1999;63:91-94.

83. Arndt KA, Bowers KE, Alam M, Reynolds R, Tsao S, eds. Warts. In: Manual of Dermatologic Therapeutics. 6th ed. Philadelphia: Lippincott, Williams \& Wilkins; 2002:241-251.

84. Dunn PM. Dr Carl Crede (1819-1892) and the prevention of ophthalmia neonatorum. Arch Dis Child Fetal Neonatal Ed 2000;83:F158-F159.

85. Hanif J, Tasca RA, Frosh A, Ghufoor K, Stirling R. Silver nitrate: histological effects of cautery on epithelial surfaces with varying contact times. Clin Otolaryngol Allied Sci 2003;28:368-370.

86. Quitkin HM, Rosenwasser MP, Strauch RJ. The efficacy of silver nitrate cauterization for pyogenic granuloma of the hand. J Hand Surg [Am] 2003;28:435-438.

87. Daniels J, Craig F, Wajed R, Meates M. Umbilical granulomas: a randomised controlled trial. Arch Dis Child Fetal Neonatal Ed 2003;88:F257.

88. Burton MJ, Doree CJ. Interventions for recurrent idiopathic epistaxis (nosebleeds) in children. Cochrane Database Syst Rev 2004;(1):CD004461.

89. Webb CJ, Beer H. Posterior nasal cautery with silver nitrate. J Laryngol Otol 2004;118:713-714. 
90. Bray Healthcare. Silver nitrate pencil instructions. Bray Group Ltd, Faringdon, Oxon, UK. Available at:

http://www.bray.co.uk/silver-nitrate-pencil.html. Accessed December 15, 2005.

91. Food and Drug Administration. Over-the-counter drug products containing colloidal silver ingredients or silver salts. Department of Health and Human Services (HHS), Public Health Service (PHS), Food and Drug Administration (FDA) Final rule. Fed Regist 1999;64:44653-44658.

92. Yazar S, Basaran E. Efficacy of silver nitrate pencils in the treatment of common warts. J Dermatol 1994;21:329-333.

93. Baumbach JL, Sheth PB. Topical and intralesional antiviral agents. In: Wolverton S, ed. Comprehensive Dermatologic Drug Therapy. Philadelphia, PA: W. B. Saunders Company; 2001:524-536.

94. Bedinghaus JM, Niedfeldt MW. Over-the-counter foot remedies. Am Fam Physician 2001;64:791-796.

95. Ahmed I, Agarwal S, Ilchyshyn A, Charles-Holmes S, Berth-Jones J. Liquid nitrogen cryotherapy of common warts: cryo-spray vs. cotton wool bud. Br J Dermatol 2001;144:1006-1009.

96. Gordon AH, Weinstein MV. Sodium salicylate iontophoresis in the treatment of plantar warts. Phys Ther 1969;49:869-870.

97. Bunney MH, Nolan MW, Williams DA. An assessment of methods of treating viral warts by comparative treatment trials based on a standard design. Br J Dermatol 1976;94:667-679.

98. Tabrizi SN, Garland SM. Is cryotherapy treating or infecting? Med J Aust 1996;164:263.

99. Connolly M, Bazmi K, O’Connell M, Lyons JF, Bourke JF. Cryotherapy of viral warts: a sustained 10 -s freeze is more effective than the traditional method. Br J Dermatol 2001;145:554-557.

100. Berth-Jones J, Bourke J, Eglitis H, Harper C, Kirk P, Pavord S, Rajapakse R, Weston P, Wiggins T, Hutchinson PE. Value of a second freeze-thaw cycle in cryotherapy of common warts. Br J Dermatol 1994;131:883-886.

101. Bourke JF, Berth-Jones J, Hutchinson PE. Cryotherapy of common viral warts at intervals of 1, 2 and 3 weeks. Br J Dermatol 1995;132:433-436.

102. Bigby M, Gibbs S, Harvey I, Sterling J. Warts. Clin Evid 2004;(11):2209-2223.

103. Kang S, Fitzpatrick TB. Debilitating verruca vulgaris in a patient infected with the human immunodeficiency virus. Dramatic improvement with hyperthermia therapy. Arch Dermatol 1994;130:294-296.

104. LoCricchio J Jr, Haserick JR. Hot-water treatment for warts. Cleve Clin Q 1962;29:156-161.

105. Dvoretzky I. Hyperthermia therapy for warts utilizing a self-administered exothermic patch. Review of two cases. Dermatol Surg 1996;22:1035-1038.

106. Kent H. Plantar wart treatment with ultrasound. Arch Phys Med Rehabil 1959;40:15-18.

107. Rowe RJ, Gray JM. Ultrasound therapy of plantar warts. Arch Dermatol 1960;82:1008-1009.

108. Cherup N, Urben J, Bender LF. The treatment of plantar warts with ultrasound. Arch Phys Med Rehabil 1963;44:602-604.

109. Cohen HJ. Warts and ultrasound therapy. Arch Dermatol 1969;100:489.

110. Griffin JE, Gersten JW. What is the best method in the use of ultrasound for the treatment of plantar warts? Phys Ther 1971;51:82-83.

111. Vaughn DT. Direct method versus underwater method in the treatment of plantar warts with ultrasound. A comparative study. Phys Ther 1973;53:396-397.

112. Braatz JH, McAlistar BR, Broaddus MD. Ultrasound and plantar warts: a double blind study. Mil Med 1974;139:199-201.
113. Zaza M, Grassi C, Mardjonovic A, Valli E, Farne C, Romanini $\mathrm{C}$. The use of electrosurgery in the treatment of extra-cervical genital condylomatosis. Minerva Ginecol 1998;50:367-371.

114. Tosti A, Piraccini BM. Warts of the nail unit: surgical and nonsurgical approaches. Dermatol Surg 2001;27:235-239.

115. Li HX, Zhu WY, Xia MY. Detection with the polymerase chain reaction of human papillomavirus DNA in condylomata acuminata treated with $\mathrm{CO} 2$ laser and microwave. Int J Dermatol 1995;34:209-211.

116. Bekassy Z, Westrom L. Infrared coagulation in the treatment of condyloma acuminata in the female genital tract. Sex Transm Dis 1987;14:209-212.

117. Piskin S, Aksoz T, Gorgulu A. The treatment of common warts with infrared coagulation. J Dermatol 2004;31:989-992.

118. Serour F, Somekh E. Successful treatment of recalcitrant warts in pediatric patients with carbon dioxide laser. Eur J Pediatr Surg 2003;13:219-223.

119. Lauchli S, Kempf W, Dragieva G, Burg G, Hafner J. CO2 laser treatment of warts in immunosuppressed patients. Dermatology 2003;206:148-152.

120. Ozluer SM, Chuen BY, Barlow RJ, Markey AC. Hypertrophic scar formation following carbon dioxide laser ablation of plantar warts in cyclosporin-treated patients. Br J Dermatol 2001;145:1005-1007.

121. Garden JM, O’Banion MK, Shelnitz LS, Pinski KS, Bakus AD, Reichmann ME, Sundberg JP. Papillomavirus in the vapor of carbon dioxide laser-treated verrucae. JAMA 1988;259:1199-1202.

122. Garden JM, O’Banion MK, Bakus AD, Olson C. Viral disease transmitted by laser-generated plume (aerosol). Arch Dermatol 2002;138:1303-1307.

123. Sawchuk WS, Weber PJ, Lowy DR, Dzubow LM. Infectious papillomavirus in the vapor of warts treated with carbon dioxide laser or electrocoagulation: detection and protection. J Am Acad Dermatol 1989;21:41-49.

124. Kashima HK, Kessis T, Mounts P, Shah K. Polymerase chain reaction identification of human papillomavirus DNA in $\mathrm{CO} 2$ laser plume from recurrent respiratory papillomatosis. Otolaryngol Head Neck Surg 1991;104:191-195.

125. Gloster HM Jr, Roenigk RK. Risk of acquiring human papillomavirus from the plume produced by the carbon dioxide laser in the treatment of warts. J Am Acad Dermatol 1995;32:436-441.

126. Tanzi EL, Bader RS. Cutaneous laser resurfacing: Erbium:YAG. eMedicine Web site. Available at: http://www.emedicine.com/derm/topic554.htm. Accessed December 28, 2005.

127. Park JH, Hwang ES, Kim SN, Kye YC. Er:YAG laser treatment of verrucous epidermal nevi. Dermatol Surg 2004;30:378-381.

128. Wollina U. Er:YAG laser followed by topical podophyllotoxin for hard-to-treat palmoplantar warts. J Cosmet Laser Ther 2003;5:35-37.

129. Hughes PS, Hughes AP. Absence of human papillomavirus DNA in the plume of erbium:YAG laser-treated warts. J Am Acad Dermatol 1998;38:426-428.

130. Pfau A, Abd-el-Raheem TA, Baumler W, Hohenleutner U, Landthaler M. Nd:YAG laser hyperthermia in the treatment of recalcitrant verrucae vulgares (Regensburg's technique). Acta Derm Venereol 1994;74:212-214.

131. Pfau A, Abd-El-Raheem TA, Baumler W, Hohenleutner U, Landthaler M. Treatment of recalcitrant verrucae vulgares with Nd: YAG laser hyperthermia (Regensburg's technique): preliminary results in 31 cases. J Dermatol Treat 1995;6:39-42.

132. El-Tonsy MH, Anbar TE, El-Domyati M, Barakat M. Density of viral particles in pre and post Nd: YAG laser hyperthermia therapy and cryotherapy in plantar warts. Int J Dermatol 1999;38:393-398. 
133. Janda P, Leunig A, Sroka R, Betz CS, Rasp G. Preliminary report of endolaryngeal and endotracheal laser surgery of juvenile-onset recurrent respiratory papillomatosis by Nd:YAG laser and a new fiber guidance instrument. Otolaryngol Head Neck Surg 2004;131:44-49.

134. Buzalov S, Khristakieva E. Condylomata acuminata. The correlation between affecting sexual partners and the risk of developing preneoplasia of the cervix uteri. The therapeutic potentials of the Nd-Yag laser. Akush Ginekol (Sofiia). 1999;38(3):36-38.

135. Izumi T, Kyushima N, Genda T, Kobayashi N, Kanai T, Wakita K, Kuramoto H. Margin clearance and HPV infection do not influence the cure rates of early neoplasia of the uterine cervix by laser conization. Eur J Gynaecol Oncol 2000;21:251-254.

136. Wu C, Langan S, Kilmurray M, Lawlor D, Watson R. Efficacy of pulsed-dye laser for viral warts - an internal audit. Ir Med J 2003;96:80, 82-83.

137. Kopera D. Verrucae vulgares: flashlamp-pumped pulsed dye laser treatment in 134 patients. Int J Dermatol 2003;42:905-908.

138. Tuncel A, Gorgu M, Ayhan M, Deren O, Erdogan B. Treatment of anogenital warts by pulsed dye laser. Dermatol Surg 2002;28:350-352.

139. Vargas H, Hove CR, Dupree ML, Williams EF. The treatment of facial verrucae with the pulsed dye laser. Laryngoscope 2002; 112:1573-1576.

140. Tan OT, Hurwitz RM, Stafford TJ. Pulsed dye laser treatment of recalcitrant verrucae: a preliminary report. Lasers Surg Med 1993;13:127-137.

141. Kauvar AN, McDaniel DH, Geronemus RG. Pulsed dye laser treatment of warts. Arch Fam Med 1995;4:1035-1040.

142. Huilgol SC, Barlow RJ, Markey AC. Failure of pulsed dye laser therapy for resistant verrucae. Clin Exp Dermatol 1996;21:93-95.

143. Jain A, Storwick GS. Effectiveness of the $585 \mathrm{~nm}$ flashlamp-pulsed tunable dye laser (PTDL) for treatment of plantar verrucae. Lasers Surg Med 1997;21:500-505.

144. Jacobsen E, McGraw R, McCagh S. Pulsed dye laser efficacy as initial therapy for warts and against recalcitrant verrucae. Cutis 1997;59:206-208.

145. Kenton-Smith J, Tan ST. Pulsed dye laser therapy for viral warts. Br J Plast Surg 1999;52:554-558.

146. Ross BS, Levine VJ, Nehal K, Tse Y, Ashinoff R. Pulsed dye laser treatment of warts: an update. Dermatol Surg 1999;25:377-380.

147. Robson KJ, Cunningham NM, Kruzan KL, Patel DS, Kreiter CD, O'Donnell MJ, Arpey CJ. Pulsed-dye laser versus conventional therapy in the treatment of warts: a prospective randomized trial. J Am Acad Dermatol 2000;43:275-280.

148. Gooptu C, James MP. Recalcitrant viral warts: results of treatment with the KTP laser. Clin Exp Dermatol 1999;24:60-63.

149. Garcia-Zuazaga J, Cooper KD, Baron ED. Photodynamic therapy in dermatology: current concepts in the treatment of skin cancer. Expert Rev Anticancer Ther 2005;5:791-800.

150. Casas A, Batlle A. Rational design of 5-aminolevulinic acid derivatives aimed at improving photodynamic therapy. Curr Med Chem Anticancer Agents 2002;2:465-475.

151. Uebelhoer NS, Dover JS. Photodynamic therapy for cosmetic applications. Dermatol Ther 2005; 18:242-252.

152. Fehr MK, Chapman CF, Krasieva T, Tromberg BJ, McCullough JL, Berns MW, Tadir Y. Selective photosensitizer distribution in vulvar condyloma acuminatum after topical application of 5-aminolevulinic acid. Am J Obstet Gynecol 1996;174:951-957.
153. Fehr MK, Hornung R, Degen A, Schwarz VA, Fink D, Haller U, Wyss P. Photodynamic therapy of vulvar and vaginal condyloma and intraepithelial neoplasia using topically applied 5-aminolevulinic acid. Lasers Surg Med 2002;30:273-279.

154. Stefanaki IM, Georgiou S, Themelis GC, Vazgiouraki EM, Tosca AD. In vivo fluorescence kinetics and photodynamic therapy in condylomata acuminata. Br J Dermatol 2003;149:972-976.

155. Wang XL, Wang HW, Wang HS, Xu SZ, Liao KH, Hillemanns P. Topical 5-aminolaevulinic acid-photodynamic therapy for the treatment of urethral condylomata acuminata. Br J Dermatol 2004;151:880-885.

156. Ross EV, Romero R, Kollias N, Crum C, Anderson RR. Selectivity of protoporphyrin IX fluorescence for condylomata after topical application of 5-aminolaevulinic acid: implications for photodynamic treatment. $\mathrm{Br} \mathrm{J}$ Dermatol 1997;137:736-742.

157. Stender IM, Lock-Andersen J, Wulf HC. Recalcitrant hand and foot warts successfully treated with photodynamic therapy with topical 5-aminolaevulinic acid: a pilot study. Clin Exp Dermatol 1999;24:154-159.

158. Stender IM, Na R, Fogh H, Gluud C, Wulf HC. Photodynamic therapy with 5-aminolaevulinic acid or placebo for recalcitrant foot and hand warts: randomised double-blind trial. Lancet 2000;355:963-966.

159. Mizuki D, Kaneko T, Hanada K. Successful treatment of topical photodynamic therapy using 5-aminolevulinic acid for plane warts. Br J Dermatol 2003;149:1087-1088.

160. Schroeter CA, Pleunis J, van Nispen tot Pannerden C, Reineke T, Neumann HA. Photodynamic therapy: new treatment for therapy-resistant plantar warts. Dermatol Surg 2005;31:71-75.

161. Fabbrocini G, Di Costanzo MP, Riccardo AM, Quarto M, Colasanti A, Roberti G, Monfrecola G. Photodynamic therapy with topical delta-aminolaevulinic acid for the treatment of plantar warts. J Photochem Photobiol B 2001;61:30-34.

162. Bhat RM, Vidya K, Kamath G. Topical formic acid puncture technique for the treatment of common warts. Int J Dermatol 2001;40:415-419.

163. Andrei G, Snoeck R, Piette J, Delvenne P, De Clercq E. Antiproliferative effects of acyclic nucleoside phosphonates on human papillomavirus (HPV)-harboring cell lines compared with HPV-negative cell lines. Oncol Res 1998; 10:523-531.

164. De Clercq E, Andrei G, Balzarini J, Hatse S, Liekens S, Naesens L, Neyts J, Snoeck R. Antitumor potential of acyclic nucleoside phosphonates. Nucleosides Nucleotides 1999;18:759-771.

165. De Clercq E, Andrei G, Balzarini J, Leyssen P, Naesens L, Neyts J, Pannecouque C, Snoeck R, Ying C, Hockova D, Holy A. Antiviral potential of a new generation of acyclic nucleoside phosphonates, the 6-[2 (phosphonomethoxy)alkoxy]-2, 4-diaminopyrimidines. Nucleosides Nucleotides Nucleic Acids 2005;24:331-341.

166. Hengge UR, Tietze G. Successful treatment of recalcitrant condyloma with topical cidofovir. Sex Transm Infect 2000;76:143.

167. Schurmann D, Bergmann F, Temmesfeld-Wollbruck B, Grobusch MP, Suttorp N. Topical cidofovir is effective in treating extensive penile condylomata acuminata. AIDS 2000;14:1075-1076.

168. Snoeck R, Noel JC, Muller C, De Clercq E, Bossens M. Cidofovir, a new approach for the treatment of cervix intraepithelial neoplasia grade III (CIN III). J Med Virol 2000;60:205-209. 
169. Orlando G, Fasolo MM, Beretta R, Signori R, Adriani B, Zanchetta N, Cargnel A. Intralesional or topical cidofovir (HPMPC, VISTIDE) for the treatment of recurrent genital warts in HIV-1-infected patients. AIDS 1999;13:1978-1980.

170. Matteelli A, Beltrame A, Graifemberghi S, Forleo MA, Gulletta M, Ciravolo G, Tedoldi S, Casalini C, Carosi G. Efficacy and tolerability of topical $1 \%$ cidofovir cream for the treatment of external anogenital warts in HIV-infected persons. Sex Transm Dis 2001;28:343-346.

171. Turnbull JR, Husak R, Treudler R, Zouboulis CC, Orfanos $\mathrm{CE}$. Regression of multiple viral warts in a human immunodeficiency virus-infected patient treated by triple antiretroviral therapy. Br J Dermatol 2002;146:330.

172. van der Velden EM, Ijsselmuiden OE, Drost BH, Baruchin AM. Dermatography with bleomycin as a new treatment for verrucae vulgaris. Int J Dermatol 1997;36:145-150.

173. Sobh MA, Abd El-Razic MM, Rizc RA, Eid MM, Abd el-Hamid IA, Ghoneim MA. Intralesional injection of bleomycin sulphate into resistant warts in renal transplant recipients versus non-transplant warty patients. Acta Derm Venereol 1991;71:63-66.

174. James MP, Collier PM, Aherne W, Hardcastle A, Lovegrove S. Histologic, pharmacologic, and immunocytochemical effects of injection of bleomycin into viral warts. J Am Acad Dermatol 1993;28:933-937.

175. Epstein E. Intralesional bleomycin and Raynaud's phenomenon. J Am Acad Dermatol 1991;24:785-786.

176. Vanhooteghem O, Richert B, de la Brassinne M. Raynaud phenomenon after treatment of verruca vulgaris of the sole with intralesional injection of bleomycin. Pediatr Dermatol 2001;18:249-251.

177. Abess A, Keel DM, Graham BS. Flagellate hyperpigmentation following intralesional bleomycin treatment of verruca plantaris. Arch Dermatol 2003;139:337-339.

178. Shumer SM, O'Keefe EJ. Bleomycin in the treatment of recalcitrant warts. J Am Acad Dermatol 1983;9:91-96.

179. Sollitto RJ, Pizzano DM. Bleomycin sulfate in the treatment of mosaic plantar verrucae: a follow-up study. J Foot Ankle Surg 1996;35:169-172.

180. Shelley WB, Shelley ED. Intralesional bleomycin sulfate therapy for warts. A novel bifurcated needle puncture technique. Arch Dermatol 1991;127:234-236.

181. Werfel S, Wolff H. Bleomycin prick in therapy-resistant verruca vulgaris. Hautarzt. 2001;52:638-641.

182. Munn SE, Higgins E, Marshall M, Clement M. A new method of intralesional bleomycin therapy in the treatment of recalcitrant warts. Br J Dermatol 1996;135:969-971.

183. Jason J, Archibald LK, Nwanyanwu OC, Sowell AL, Buchanan I, Larned J, Bell M, Kazembe PN, Dobbie H, Jarvis WR. Vitamin A levels and immunity in humans. Clin Diagn Lab Immunol 2002;9:616-621.

184. Bartsch D, Boye B, Baust C, zur Hausen H, Schwarz E. Retinoic acid-mediated repression of human papillomavirus 18 transcription and different ligand regulation of the retinoic acid receptor beta gene in non-tumorigenic and tumorigenic HeLa hybrid cells. EMBO J 1992;11:2283-2291.

185. Faluhelyi Z, Rodler I, Csejtey A, Tyring SK, Ember IA, Arany I. All-trans retinoic acid (ATRA) suppresses transcription of human papillomavirus type 16 (HPV16) in a dose-dependent manner. Anticancer Res 2004;24:807-809.

186. Kubeyinje EP. Evaluation of the efficacy and safety of $0.05 \%$ tretinoin cream in the treatment of plane warts in Arab children. J Dermatol Treat 1996;7:21-22.

187. Gelmetti C, Cerri D, Schiuma AA, Menni S. Treatment of extensive warts with etretinate: a clinical trial in 20 children. Pediatr Dermatol 1987;4:254-258.
188. Boyle J, Dick DC, MacKie RM. Treatment of extensive virus warts with etretinate (Tigason) in a patient with sarcoidosis. Clin Exp Dermatol 1983;8:33-36.

189. Gross G, Pfister H, Hagedorn M, Stahn R. Effect of oral aromatic retinoid (Ro 10-9359) on human papilloma virus-2-induced common warts. Dermatologica 1983;166:48-53.

190. Tsambaos D, Georgiou S, Monastirli A, Sakkis T, Sagriotis A, Goerz G. Treatment of condylomata acuminata with oral isotretinoin. J Urol 1997;158:1810-1812.

191. Georgala S, Katoulis AC, Georgala C, Bozi E, Mortakis A. Oral isotretinoin in the treatment of recalcitrant condylomata acuminata of the cervix: a randomised placebo controlled trial. Sex Transm Infect 2004;80:216-218.

192. Abu J, Batuwangala M, Herbert K, Symonds P Retinoic acid and retinoid receptors: potential chemopreventive and therapeutic role in cervical cancer. Lancet Oncol 2005;6:712-720.

193. Schwartz J, Norton SA. Useful plants of dermatology. VI. The mayapple (Podophyllum). J Am Acad Dermatol 2002;47:774-775.

194. Fondren BT. Mayapple. Ethnobotanical leaflets, a publication of the Southern Illinois University Herbariaum. Available at: http://www.siu.edu/ ebl/leaflets/mayapple.htm. Accessed December 7, 2005.

195. Kaplan IW. Condylomata acuminate. N Orleans Med Surg J 1942;93:388.

196. Nelson LM. Use of podophyllin (podophyllum resin) in dermatology. AMA Arch Derm Syphilol 1953;67:488-495

197. Stone KM, Becker TM, Hadgu A, Kraus SJ. Treatment of external genital warts: a randomised clinical trial comparing podophyllin, cryotherapy, and electrodesiccation. Genitourin Med 1990;66:16-19

198. The Condylomata International Collaborative Study Group. A comparison of interferon alfa-2a and podophyllin in the treatment of primary condylomata acuminata. Genitourin Med 1991;67:394-399.

199. Goh CL, Ang CB, Chan RK, Cheong WK. Comparing treatment response and complications between podophyllin $0.5 \% / 0.25 \%$ in ethanol vs podophyllin $25 \%$ in tincture benzoin for penile warts. Singapore Med J 1998;39:17-19.

200. Gabriel G, Thin RN. Treatment of anogenital warts. Comparison of trichloracetic acid and podophyllin versus podophyllin alone. Br J Vener Dis 1983;59:124-126.

201. von Krogh G, Wikstrom A. Efficacy of chemical and/or surgical therapy against condylomata acuminata: a retrospective evaluation. Int J STD AIDS 1991;2:333-338.

202. Mohanty KC. The cost effectiveness of treatment of genital warts with podophyllotoxin. Int J STD AIDS 1994;6:253-256.

203. von Krogh G. Management of anogenital warts (condylomata acuminata). Eur J Dermatol 2001;11:598-603.

204. von Krogh G, Longstaff E. Podophyllin office therapy against condyloma should be abandoned. Sex Transm Infect 2001;77:409-412.

205. Lacey CJ, Goodall RL, Tennvall GR, Maw R, Kinghorn GR, Fisk PG, Barton S, Byren I; Perstop Pharma Genital Warts Clinical Trial Group. Randomised controlled trial and economic evaluation of podophyllotoxin solution, podophyllotoxin cream, and podophyllin in the treatment of genital warts. Sex Transm Infect 2003;79:270-275.

206. Filley CM, Graff-Richard NR, Lacy JR, Heitner MA, Earnest MP. Neurologic manifestations of podophyllin toxicity. Neurology 1982;32:308-311.

207. Chattopadhyay S, Srivastava AK, Bhojwani SS, Bisaria VS. Production of podophyllotoxin by plant cell cultures of Podophyllum hexandrum in bioreactor. J Biosci Bioeng 2002;93:215-220.

208. Seif R. Factors which disorganize microtubules or microfilaments increase the frequency of cell transformation by polyoma virus. J Virol 1980;36:421-428. 
209. Kirby P, Dunne A, King DH, Corey L. Double-blind randomized clinical trial of self-administered podofilox solution versus vehicle in the treatment of genital warts. Am J Med 1990;88:465-469.

210. Hellberg D, Svarrer T, Nilsson S, Valentin J. Self-treatment of female external genital warts with $0.5 \%$ podophyllotoxin cream (Condyline) vs weekly applications of $20 \%$ podophyllin solution. Int J STD AIDS 1995;6:257-261.

211. Ibs KH, Rink L. Zinc-altered immune function. J Nutr 2003; 133:1452S-1526S.

212. Fraker PJ, King LE. Reprogramming of the immune system during zinc deficiency. Annu Rev Nutr 2004;24:277-298.

213. Al-Gurairi FT, Al-Waiz M, Sharquie KE. Oral zinc sulphate in the treatment of recalcitrant viral warts: randomized placebo-controlled clinical trial. Br J Dermatol 2002;146:423-431.

214. Upitis JA, Krol A. The use of diphenylcyclopropenone in the treatment of recalcitrant warts. J Cutan Med Surg 2002;6:214-217.

215. Higgins E, du Vivier A. Topical immunotherapy: unapproved uses, dosages, or indications. Clin Dermatol 2002;20:515-521.

216. Buckley DA, Keane FM, Munn SE, Fuller LC, Higgins EM, Du Vivier AW. Recalcitrant viral warts treated by diphencyprone immunotherapy. Br J Dermatol 1999;141:292-296.

217. Friedman-Kien AE, Eron LJ, Conant M, Growdon W, Badiak H, Bradstreet PW, Fedorczyk D, Trout JR, Plasse TF. Natural interferon alfa for treatment of condylomata acuminata. JAMA 1988;259:533-538.

218. Lozada-Nur F, Glick M, Schubert M, Silverberg I. Use of intralesional interferon-alpha for the treatment of recalcitrant oral warts in patients with AIDS: a report of 4 cases. Oral Surg Oral Med Oral Pathol Oral Radiol Endod 2001;92:617-622.

219. Johnson SM, Roberson PK, Horn TD. Intralesional injection of mumps or Candida skin test antigens: a novel immunotherapy for warts. Arch Dermatol 2001;137:451-455.

220. Signore RJ. Candida albicans intralesional injection immunotherapy of warts. Cutis 2002;70:185-192.

221. Perman M, Sterling JB, Gaspari A. The painful purple digit: an alarming complication of Candida albicans antigen treatment of recalcitrant warts. Dermatitis 2005;16:38-40.

222. Iscimen A, Aydemir EH, Goksugur N, Engin B. Intralesional 5-fluorouracil, lidocaine and epinephrine mixture for the treatment of verrucae: a prospective placebo-controlled, single-blind randomized study. J Eur Acad Dermatol Venereol 2004;18:455-458.

223. Rogers CJ, Gibney MD, Siegfried EC, Harrison BR, Glaser DA. Cimetidine therapy for recalcitrant warts in adults: is it any better than placebo? J Am Acad Dermatol 1999;41:123-127.

224. Mitsuishi T, Iida K, Kawana S. Cimetidine treatment for viral warts enhances IL-2 and IFN-gamma expression but not IL-18 expression in lesional skin. Eur J Dermatol 2003;13:445-448.

225. Karabulut AA, Sahin S, Eksioglu M. Is cimetidine effective for nongenital warts: a double-blind, placebo-controlled study. Arch Dermatol 1997;133:533-534.

226. Yilmaz E, Alpsoy E, Basaran E. Cimetidine therapy for warts: a placebo-controlled, double-blind study. J Am Acad Dermatol 1996;34:1005-1007.

227. Mullen BR, Guiliana JV, Nesheiwat F. Cimetidine as a first-line therapy for pedal verruca: eight-year retrospective analysis. J Am Podiatr Med Assoc 2005;95:229-234.

228. Amer M, Tosson Z, Soliman A, Selim AG, Salem A, al-Gendy AA. Verrucae treated by levamisole. Int J Dermatol 1991;30:738-740.

229. Hengge UR, Esser S, Schultewolter T, Behrendt C, Meyer T, Stockfleth E, Goos M. Self-administered topical 5\% imiquimod for the treatment of common warts and molluscum contagiosum. Br J Dermatol 2000;143:1026-1031.
230. Micali G, Dall'Oglio F, Nasca MR. An open label evaluation of the efficacy of imiquimod 5\% cream in the treatment of recalcitrant subungual and periungual cutaneous warts. J Dermatolog Treat 2003;14:233-236.

231. Poochareon V, Berman B, Villa A. Successful treatment of butcher's warts with imiquimod 5\% cream. Clin Exp Dermatol 2003;28(Suppl 1):42-44.

232. Sauder DN, Skinner RB, Fox TL, Owens ML. Topical imiquimod $5 \%$ cream as an effective treatment for external genital and perianal warts in different patient populations. Sex Transm Dis 2003;30:124-128.

233. Zamiri M, Gupta G. Plantar warts treated with an immune response modifier: a report of two cases. Clin Exp Dermatol 2003;28(Suppl 1):45-47.

234. Hesterberg U, Bohlen LM, Brand CU. Imiquimod in the treatment of recalcitrant warts: a new therapy option? Schweiz Rundsch Med Prax. 2003;92:535-539.

235. Arican O, Guneri F, Bilgic K, Karaoglu A. Topical imiquimod $5 \%$ cream in external anogenital warts: a randomized, double-blind, placebo-controlled study. J Dermatol 2004;31:627-631.

236. Hoyme UB, Hagedorn M, Schindler AE, Schneede P, Hopfenmuller W, Schorn K, Eul A. Effect of adjuvant imiquimod 5\% cream on sustained clearance of anogenital warts following laser treatment. Infect Dis Obstet Gynecol 2002; 10:79-88.

237. Skinner RB Jr. Imiquimod. Dermatol Clin 2003;21:291-300.

238. Alexandroff AB, Jackson AM, O’Donnell MA, James K. BCG immunotherapy of bladder cancer: 20 years on. Lancet 1999;353:1689-1694.

239. Bohle A, Thanhauser A, Ulmer AJ, Ernst M, Flad HD, Jocham D. Dissecting the immunobiological effects of Bacillus Calmette-Guerin (BCG) in vitro: evidence of a distinct BCG-activated killer (BAK) cell phenomenon. J Urol 1993; 150:1932-1937.

240. Bohle A, Thanhauser A, Ulmer AJ, Mattern T, Ernst M, Flad HD, Jocham D. On the mode of action of intravesical bacillus Calmette-Guerin: in vitro characterization of BCG-activated killer cells. Urol Res 1994;22:185-190.

241. Guidotti LG, Chisari FV. To kill or to cure: options in host defense against viral infection. Curr Opin Immunol 1996;8:478-483.

242. Kershaw MH, Trapani JA, Smyth MJ. Cytotoxic lymphocytes: redirecting the cell-mediated immune response for the therapy of cancer. Ther Immunol 1995;2:173-181.

243. Bohle A, Doehn C, Kausch I, Jocham D. Treatment of recurrent penile condylomata acuminata with external application and intraurethral instillation of bacillus Calmette-Guerin. J Urol 1998; 160:394-396.

244. Bohle A, Buttner H, Jocham D. Primary treatment of condylomata acuminata with viable bacillus Calmette-Guerin. J Urol 2001;165:834-836.

245. Metawea B, El-Nashar AR, Kamel I, Kassem W, Shamloul R. Application of viable bacille Calmette-Guerin topically as a potential therapeutic modality in condylomata acuminata: a placebo-controlled study. Urology 2005;65:247-250.

246. Abcarian H, Sharon N. Long-term effectiveness of the immunotherapy of anal condyloma acuminatum. Dis Colon Rectum 1982;25:648-651.

247. Harper DM. Are we closer to the prevention of HPV-related diseases? J Fam Pract 2005;54(7 Suppl):S10-S16.

248. Hussain SF, Paterson Y. What is needed for effective antitumor immunotherapy? Lessons learned using Listeria monocytogenes as a live vector for HPV-associated tumors. Cancer Immunol Immunother 2005;54:577-586.

249. Kahn JA, Bernstein DI. Human papillomavirus vaccines and adolescents. Curr Opin Obstet Gynecol 2005;17:476-482. 
250. Kahn JA, Zimet GD, Bernstein DI, Riedesel JM, Lan D, Huang B, Rosenthal SL. Pediatricians' intention to administer human papillomavirus vaccine: the role of practice characteristics, knowledge, and attitudes. J Adolesc Health 2005;37:502-510.

251. Williamson AL, Passmore JA, Rybicki EP. Strategies for the prevention of cervical cancer by human papillomavirus vaccination. Best Pract Res Clin Obstet Gynaecol 2005;19:531-544.

252. Yang R, Wheeler CM, Chen X, Uematsu S, Takeda K, Akira S, Pastrana DV, Viscidi RP, Roden RB. Papillomavirus capsid mutation to escape dendritic cell-dependent innate immunity in cervical cancer. J Virol 2005;79:6741-6750.

253. Zhou J, Sun XY, Stenzel DJ, Frazer IH. Expression of vaccinia recombinant HPV $16 \mathrm{~L} 1$ and L2 ORF proteins in epithelial cells is sufficient for assembly of HPV virion-like particles. Virology 1991;185:251-257

254. Poland GA, Jacobson RM, Koutsky LA, Tamms GM, Railkar R, Smith JF, Bryan JT, Cavanaugh PF Jr, Jansen KU, Barr E. Immunogenicity and reactogenicity of a novel vaccine for human papillomavirus 16: a 2-year randomized controlled clinical trial. Mayo Clin Proc 2005;80:601-610.

255. Brown DR, Bryan JT, Schroeder JM, Robinson TS, Fife KH, Wheeler CM, Barr E, Smith PR, Chiacchierini L, DiCello A, Jansen KU. Neutralization of human papillomavirus type 11 (HPV-11) by serum from women vaccinated with yeast-derived HPV-11 L1 virus-like particles: correlation with competitive radioimmunoassay titer. J Infect Dis 2001;184:1183-1186.

256. Emeny RT, Wheeler CM, Jansen KU, Hunt WC, Fu TM, Smith JF, MacMullen S, Esser MT, Paliard X. Priming of human papillomavirus type 11-specific humoral and cellular immune responses in college-aged women with a virus-like particle vaccine. J Virol 2002;76:7832-7842.

257. Brown DR, Fife KH, Wheeler CM, Koutsky LA, Lupinacci LM, Railkar R, Suhr G, Barr E, Dicello A, Li W, Smith JF, Tadesse A, Jansen KU. Early assessment of the efficacy of a human papillomavirus type $16 \mathrm{~L} 1$ virus-like particle vaccine. Vaccine 2004;22:2936-2942.

258. Fife KH, Wheeler CM, Koutsky LA, Barr E, Brown DR, Schiff MA, Kiviat NB, Jansen KU, Barber H, Smith JF, Tadesse A, Giacoletti K, Smith PR, Suhr G, Johnson DA. Dose-ranging studies of the safety and immunogenicity of human papillomavirus Type 11 and Type 16 virus-like particle candidate vaccines in young healthy women. Vaccine 2004;22:2943-2952.

259. Ault KA, Giuliano AR, Edwards RP, Tamms G, Kim LL, Smith JF, Jansen KU, Allende M, Taddeo FJ, Skulsky D, Barr E. A phase I study to evaluate a human papillomavirus (HPV) type 18 L1 VLP vaccine. Vaccine 2004;22:3004-3007.

260. Koutsky LA, Ault KA, Wheeler CM, Brown DR, Barr E, Alvarez FB, Chiacchierini LM, Jansen KU; Proof of Principle Study Investigators. A controlled trial of a human papillomavirus type 16 vaccine. N Engl J Med 2002;347:1645-1651.

261. Harper DM, Franco EL, Wheeler C, Ferris DG, Jenkins D, Schuind A, Zahaf T, Innis B, Naud P, De Carvalho NS, Roteli-Martins CM, Teixeira J, Blatter MM, Korn AP, Quint W, Dubin G; GlaxoSmithKline HPV Vaccine Study Group. Efficacy of a bivalent L1 virus-like particle vaccine in prevention of infection with human papillomavirus types 16 and 18 in young women: a randomised controlled trial. Lancet 2004;364:1757-1765.

262. Lowndes CM, Gill ON. Cervical cancer, human papillomavirus, and vaccination. BMJ 2005;331:915-916.

263. Finn A. Details of HPV immunisation need not delay decision. BMJ 2005;331:1081.

264. Gill ON, Lowndes CM. Data are still needed for HPV immunisation programme. BMJ 2005;331:1204.
265. WHO. WHO consultation on human papillomavirus vaccines. Wkly Epidemiol Rec 2005;80:299-302.

266. Grunbaum JA, Kann L, Kinchen S, Ross J, Hawkins J, Lowry R, Harris WA, McManus T, Chyen D, Collins J. Youth risk behavior surveillance-United States, 2003. MMWR Surveill Summ 2004;53:1-96.

267. Soubeyrand B, Leparc J. Vaccination against human papillomavirus: a new vaccination for the female adolescent? Med Mal Infect 2005 Oct 24; [Epub ahead of print].

268. Washam C. Targeting teens and adolescents for HPV vaccine could draw fire. J Natl Cancer Inst 2005;97:1030-1031.

269. Kulasingam SL, Myers ER. Potential health and economic impact of adding a human papillomavirus vaccine to screening programs. JAMA 2003;290:781-789.

270. Goldie SJ, Kim JJ, Wright TC. Cost-effectiveness of human papillomavirus DNA testing for cervical cancer screening in women aged 30 years or more. Obstet Gynecol 2004;103:619-631.

271. Castle PE, Schiffman M, Herrero R, Hildesheim A, Rodriguez AC, Bratti MC, Wacholder S, Kendal H, Breheny AM, Prior A, Pfeiffer R, Burk RD. PCR testing of pooled longitudinally collected cervical specimens of women to increase the efficiency of studying human papillomavirus infection. Cancer Epidemiol Biomarkers Prev 2005; 14:256-260.

272. Denny L, Kuhn L, De Souza M, Pollack AE, Dupree W, Wright TC Jr. Screen-and-treat approaches for cervical cancer prevention in low-resource settings: a randomized controlled trial. JAMA 2005;294:2173-2181.

273. Kim JJ, Wright TC, Goldie SJ. Cost-effectiveness of human papillomavirus DNA testing in the United Kingdom, The Netherlands, France, and Italy. J Natl Cancer Inst 2005;97:888-895.

274. Mayneux EJ Jr. Overcoming barriers to HPV vaccine acceptance. J Fam Pract 2005;54:S17-S22.

275. Olshen E, Woods ER, Austin SB, Luskin M, Bauchner H. Parental acceptance of the human papillomavirus vaccine. J Adolesc Health 2005;37:248-251.

276. Gravitt PE, Shah KV. A Virus-based Vaccine May Prevent Cervical Cancer. Curr Infect Dis Rep 2005;7:125-131.

277. Bushley AW, Cassel K, Hernandez BY, Robinett H, Goodman MT. A tailored multi-media campaign to promote the human papillomavirus cohort study to young women. Prev Med 2005;41:98-101.

278. McClean H, Shann S. A cross-sectional survey of treatment choices for anogenital warts. Int J STD AIDS 2005;16:212-216.

279. Sparling JD, Checketts SR, Chapman MS. Imiquimod for plantar and periungual warts. Cutis 2001;68:397-399.

280. Tucker SB, Ali A, Ransdell BL. Plantar wart treatment with combination imiquimod and salicylic acid pads. J Drugs Dermatol 2003;2:124-126.

281. Housman TS, Jorizzo JL. Anecdotal reports of 3 cases illustrating a spectrum of resistant common warts treated with cryotherapy followed by topical imiquimod and salicylic acid. J Am Acad Dermatol 2002;47:S217-S220.

282. Young S, Cohen GE. Treatment of verruca plantaris with a combination of topical fluorouracil and salicylic acid. J Am Podiatr Med Assoc 2005;95:366-369.

283. Olsen EA, Kelly FF, Vollmer RT, Buddin DA, Weck PK. Comparative study of systemic interferon alfa-nl and isotretinoin in the treatment of resistant condylomata acuminata. J Am Acad Dermatol 1989;20:1023-1030.

284. Cardamakis E, Kotoulas IG, Relakis K, Metalinos K, Michopoulos J, Stathopoulos E, Mantouvalos H. Comparative study of systemic interferon alfa-2a plus isotretinoin versus isotretinoin in the treatment of recurrent condyloma acuminatum in men. Urology 1995;45:857-860. 
285. Cardamakis EK, Kotoulas IG, Dimopoulos DP, Stathopoulos EN, Michopoulos JT, Tzingounis VA. Comparative study of systemic interferon alfa-2a with oral isotretinoin and oral isotretinoin alone in the treatment of recurrent condylomata accuminata. Arch Gynecol Obstet 1996;258:35-41.

286. Yildirim M, Inaloz HS, Baysal V, Kesici D, Candir O. A case of condyloma acuminatum treated successfully with low-dose isotretinoin and interferon. Int J Clin Pract 2004;58:889-891.

287. Anadolu R, Oskay T, Erdem C, Boyvat A, Terzi E, Gurgey E. Treatment of epidermodysplasia verruciformis with a combination of acitretin and interferon alfa-2a. J Am Acad Dermatol 2001;45:296-299.

288. Gubinelli E, Posteraro P, Cocuroccia B, Girolomoni G. Epidermodysplasia verruciformis with multiple mucosal carcinomas treated with pegylated interferon alfa and acitretin. J Dermatolog Treat 2003;14:184-188.

289. Douglas JM Jr, Eron LJ, Judson FN, Rogers M, Alder MB, Taylor E, Tanner D, Peets E. A randomized trial of combination therapy with intralesional interferon alpha $2 \mathrm{~b}$ and podophyllin versus podophyllin alone for the therapy of anogenital warts. J Infect Dis 1990;162:52-59.

290. Kruse AJ, Baak JP, Janssen EA, Bol MG, Kjellevold KH, Fianne B, Lovslett K, Bergh J. Low- and high-risk CIN 1 and 2 lesions: prospective predictive value of grade, HPV, and Ki-67 immuno-quantitative variables. J Pathol 2003;199:462-470.

291. Okamoto A, Woodworth CD, Yen K, Chung J, Isonishi S, Nikaido T, Kiyokawa T, Seo H, Kitahara Y, Ochiai K, Tanaka $\mathrm{T}$. Combination therapy with podophyllin and vidarabine for human papillomavirus positive cervical intraepithelial neoplasia. Oncol Rep 1999;6:269-276.

292. Pollock B, Sheehan-Dare R. Pulsed dye laser and intralesional bleomycin for treatment of resistant viol hand warts. Lasers Surg Med 2002;30:135-140.

293. Hua Z, Gibson SL, Foster TH, Hilf R. Effectiveness of delta-aminolevulinic acid-induced protoporphyrin as a photosensitizer for photodynamic therapy in vivo. Cancer Res 1995;55:1723-1731.

294. Smucler R, Jatsova E. Comparative study of aminolevulic acid photodynamic therapy plus pulsed dye laser versus pulsed dye laser alone in treatment of viral warts. Photomed Laser Surg 2005;23:202-205.

295. Johnson SM, Horn TD. Intralesional immunotherapy for warts using a combination of skin test antigens: a safe and effective therapy. J Drugs Dermatol 2004;3:263-265.

296. Parsad D, Saini R, Negi KS. Comparison of combination of cimetidine and levamisole with cimetidine alone in the treatment of recalcitrant warts. Australas J Dermatol 1999;40:93-95.

297. Parsad D, Pandhi R, Juneja A, Negi KS. Cimetidine and levamisole versus cimetidine alone for recalcitrant warts in children. Pediatr Dermatol 2001;18:349-352.

298. Orlando G, Fasolo MM, Beretta R, Merli S, Cargnel A. Combined surgery and cidofovir is an effective treatment for genital warts in HIV-infected patients. AIDS 2002;16:447-450.

299. King E. What are NNRTIs?: An overview of how they work and their current availability. Aids Treatment Update 1996;43:e1-e2. Available at: http://www.aegis.com/pubs/atu/1996/atu4302.html. Accessed May 15, 2006.

300. Spach DH, Colven R. Resolution of recalcitrant hand warts in an HIV-infected patient treated with potent antiretroviral therapy. J Am Acad Dermatol 1999;40:818-821.

301. Roark TR, Pandya AG. Combination therapy of resistant warts in a patient with AIDS. Dermatol Surg 1998;24:1387-1389.
Author Affiliation

Michelle M. Lipke, MPAS, PA-C

Department of Dermatology

Marshfield Clinic-Wausau Center

Wausau, Wisconsin USA 